Article received on September $30^{\text {th }} 2018$

Article accepted on November $5^{\text {th }} 2018$

UDC: 78.01

781

\author{
Valentina Radoman* \\ University of Novi Sad \\ Academy of Arts \\ Department of Musicology and Ethnomusicology
}

\title{
NEW CRITICAL THINKING IN MUSICOLOGY \\ What ideologies do contemporary musicologists speak from and for whom do they speak
}

\begin{abstract}
New critical thinking in musicology has been new for at least thirty years and yet it is still opposed by many musicologists or composers or performers who Adorno-like (Theodor W. Adorno) remain devoted to the idea that the function of art in society is to be without a function. The fact is, however, that even today such an attitude is legitimate, just as much as interdisciplinary, critically oriented musicological research, which points out that music, like other arts, often hides some inappropriate reverse behind its sensuous seductiveness. Today musicologists can, based on their intellectual, educational, sensuous, class, ethical and other potentials choose the position from which to talk about music. Unlike traditional musicology which, according to some musicians, mostly addresses musicologists themselves, and only in ideal cases performers and listeners, today's interdisciplinary critical musicology, in its good examples, is indispensable to everybody: art
\end{abstract}

* Author contact information: vradoman@yahoo.com 
financiers (patrons or taxpayers), composers who are often victims of the market or serve as masks behind which oligarchs hide today, performers who choose what musical works to play and affirm and how to do it, and all listeners who are not professional musicians, but they need to be informed about various aspects of music art.

Key words: contemporary musicology, critical theories, critical potential of musicology, ideologies of interpretation of music, ideologies of the perception of music.

The subject of this paper could equally 'have a dialogue' with the themes, i.e. the contents of the books such as the book Hémisphère gauche Cartographie des nouvelles pensées critiques published five years ago by French sociologist and philosopher Razmig Keucheyan, ${ }^{1}$ or with the contents of the book The Literary Theory published thirty-five years ago by Terry Eagleton, a literary theorist, and similar books of a more recent date, ${ }^{2}$ or with numerous books by aestheticians and art theorists such as Miško Šuvaković and others, ${ }^{3}$ as with the contents of those influential books and texts from the field of musicology which examine and show, using examples, the methodological challenges and critical potential of contemporary musicology. ${ }^{4}$ Today's even wider opening of the borders of mu-

1 Razmig Keucheyan, Hémisphère gauche: Cartographie des nouvelles pensées critiques, Paris, La Découverte, 2013. (Razmig Kešejan, Leva hemisfera; Kartografija novih kritičkih mišljenja, Beograd, Fakultet za medije i komunikacije, Univerzitet Singidunum, 2016.)

2 Terry Eagleton, Literary Theory: An Introduction, University of Minnesota Press, 1983. (Terry Eagleton, prev. Mia Pervan-Plavec, Zagreb, Liber, 1987.)

3 Among the numerous books by Miško Šuvaković, it might be enough to mention here his capital work Pojmovnik teorije umetnosti (Beograd, Orion Art, 2011)) which lists and explains in detail over a thousand concepts that make up the contemporary theory of art.

4 When it comes to musicology books, it is perhaps enough to note that ever growing multinational company which has acquired many famous publishing house-the publishing house Routledge-started in 2006, in the edition Ashgate Contemporary Thinkers on Critical Musicology, re-publishing the selected books of leading musicologists in the field of critical musicology. Among those names are: Robert P. Morgan, Annegret Fauser, Derek B. Scott, Richard Leppert, Lawrence Kramer, Susan McClary and others. See: https://www.routledge. com/music/series/ACTCMS

Within the national framework one should recall the text from 1998, "Contextuality of musicology" by Mirjana Veselinović-Hofman, in a special edition of the New Sound journal, under the title Poststructuralist science of music. Unlike the short, but meaningful and important correspondence about so-called New musicology which was led, among others, by Lawrence Kramer, one of the representatives of the New musicology, and Charles Rosen, who criticized the New Musicology in the text "Music à la Mode" (The New York Review of Books, June 23, 1994), there was no criticism (written, substantiated) on the article "The contextuality of musicology" at the national level. Contrary to Rosen, his complaining reactions and certain types of futile attempts to change the course of the inevitable transforma- 
sicology as a scientific discipline to other scientific fields than was the case with the real openness of musicology to the social sciences and philology from its beginnings, ${ }^{5}$ has been providing the musicologist for a long time, since the $1980 \mathrm{~s}$, with the opportunity to achieve dialogue with the authors of scientific works from a wide range of scientific disciplines and critical theories created or implemented in them. ${ }^{6}$ This wide opening of musicology borders makes contemporary musicology the scene of various, often conflicting, contradictory thinking that is in a constant, more or less visible, struggle for supremacy in musicology or in a wider context. Using Deleuze's words, it could be said that this consideration of the inevitable transformation of musicology, with all the stimulating criticism, including unpleasant derision ${ }^{7}$ that these transformations have endured during

tion of musicology just four years earlier and Kramer's friendly but somewhat patronizing response to criticisms made against him, Veselinović-Hofman in this article states in a very calm way changes in contemporary musicology, caused, as it was explained, "by deconstructive inherence of music", and supports the observation of Rose Rosengard Subotnik, which still proves to be correct, that she couldn't see "a fatal contradiction between accepting autonomy (of music), as a sort of paradigm for interpreting the structure, and the rejection of autonomy, as epistemological ideology".

5 Although Guido Adler, as one of the founders of music science, imagines that openness to other disciplines as a full openness to all disciplines in the future that would help achieve the scientific task of unraveling all social, economic and political links between music and culture (Guido Adler, "Musik und Wissenschaft", Akademische Antrittsrede, gehalten am 26. October 1898 an der Universität Wien, Jahrbuch der Musikbibliothek Peters, 5, according to: Ivana Ilić, Epistemologija savremene muzičke analize, doktorska disertacija (rukopis), Katedra za muzikologiju, Fakultet muzičke umetnosti, Beograd, 2016, 60).

6 And indirect dialogue with the books author, and direct with contemporary authors-when joint works on the same subject can arise-seen from the angles of two or more scientific disciplines.

7 On the one hand the redicules are sent by mature scientists who, in the words of Robert S. Nelson from another context, "challenged by change, resist it and reassert the past by calling for a return to standards, usually defined as the state of the discipline that existed when they were students." On the other hand, ridicules are sent, not only to musicology, but critical theories and application of critical theory in various scientific disciplines, by scientists who have no great scientific impact like authors being written about, such as François Cusset, the author of the book French Theory: How Foucault, Derrida, Deleuze, \& Co. Transformed the Intellectual Life of the United States (French Theory: Foucault, Derrida, Deleuze \& Cie et les mutations de la vie intellectuelle aux États-Unis, Paris, La Découverte, 2003), and also those who are opponents of critical theories, in general, and for a variety of reasons: because they represent different political ideas from the majority of post-Marxist and neo-Marxist ideas that soak the field of poststructuralist critical theories, because they oppose certain attainments or defeats of critical theories, in spite of this, they are generally perceived from the negative angle, because they can use critical theories, especially French critical theory, as a 
four decades, is already a "tired thought". Nevertheless, judging by the topics from musicological symposiums, dissertations and books, this subject still requires intellectual debate, thus showing that musicology as a discipline does not have or does not want to have a scientifically stable or acceptably fluid platform, i.e. contemporary research procedures and protocols designed by scientific consensus.

Therefore, this text could talk about one kind of a reminder, a systematic overview of the various streams of thoughts that have influenced musicology from its beginnings in the 19th century to the present day. However, it is possible, but more appropriate, to achieve it in a book than in a short text. In that case, it might especially be argued about what the term 'new critical thinking' means, and particularly what the notion 'new' implies in all its layers. Because the problem of the 'new' is a special theoretical problem, while in the title of this text this notion is used more simply, in terms of something current - that critical thinking that is already an unavoidable part of the intellectual maturing of the youngest generations of scientists. ${ }^{8}$ Or, this text could make a selection and overview of the most influential critical thoughts which echoed most in musicology and contributed to significant musicological insights which could not have been reached with the means of so-called traditional musicology. Also, a negative thesis could be set and examples of musicological applications of various critical theories could be chosen, i.e. their concepts whose inadequate transition into the area of talks about music brought musicology into an awkward situation or we could talk about the methodology and concepts of newly-formed fields of research, musicological or trans-musicological, such as: popular music studies, postcolonial music studies, iconology studies, gender studies, radio studies, media and communication studies, body studies, body studies in the social context, etc.

Out of many possibilities an approach has been chosen for this paper which examines only a few concepts (Other and Ideology) which are crucial for certain

\footnotetext{
good means for placing cynicism without charm, like Christopher Butler in the book Postmodernism: A very short introduction (Oxford - New York: Oxford University Press, 2002.) and others.

8 Middle-aged and the older generations of scientists with their rich experiences and a horizon on which they can see achievements of both "traditional" and contemporary musicology ("contemporary" in the sense of "today" that inevitably had to undergo certain changes over time), or different institutions with their mechanisms of preserving the "stability" of scientific disciplines, have, unlike younger generations of scientists, the option to choose, or they may foster the still ambivalent relationship towards the transformations of musicology thereby producing either negative or stimulating tensions between "traditional" and contemporary musicology.
} 
critical theories and at the same time common for several scientific disciplines and which come to musicology from 'outside', whether the musicology of today can survive without those concepts or has to take them over and to whom the science of music serves today: the students of music, composers, performers, audience, the scientific community, a particular social class or certain social groups. It was difficult to choose, out of an impressive number of very inspiring concepts which can be used in musicology from various disciplines, ${ }^{9}$ a few that would be good as models of the changing of musical thinking since the last decades of the 20th century to the present day, and as indicators of the critical potential of musicology. Nevertheless, the mentioned choice has been made, although some other selection would be equally appropriate.

When 'critical potential' is mentioned in this text, that expression, contrary to its use in many other musicological works, is used in two meanings only. ${ }^{10}$ The first meaning of the critical potential refers to the possibility, that is, the obligation of musicology, to reconsider its established means of music research over and over again, while staying in the domain of speech about music only. The review of the effects and achievements of various types of formal analysis, or transfer/translation of the formal analysis results, expressed by harmonic and formal or structural codes, into a written narrative of a spoken language and the narrative of the history of music, the consideration of the very narrative of history or the theory of music, their fiction for example, ${ }^{11}$ or the establishment of new

9 See Tables No. 1 and No. 2. Concepts have been taken over from various scientific areas in which they have been either produced or applied and carry critical potential.

10 One shouldn't forget the fact that these two meanings can branch into many other meanings. But in this text these two meanings have been chosen as the most important ones knowing that in that way variety of shades which are characteristic of today's critical musicology in the world will be lost. However there are a lot of regions where the question of shades hasn't got its turn because there are a lot of old musicological problems to be solved.

11 Edward Said and Hayden White, among others, have reflected on the question of interpreting the facts in the field of the history of society and art in the light of the learning that the meanings are the effects of the kind of a selected narrative and therefore the discourse of the history of society or art has much more in common with fictional storytelling than the historians are ready to admit. See, for example: Edward W. Said, Orientalism, London - New York, Routledge - Kegan Paul, 1978. (Edvard Said, Orijentalizam, prev. Drinka Gojković, Beograd, Biblioteka XX vek, 2000.); Edward W. Said, Culture and Imperialism. New York, Vintage Books, 1993. (Edvard Said, Kultura i imperijalizam, prev. Vesna Bogojević, Beograd, Čigoja štampa/Beogradski krug, 2002.); Hayden White, The Content and the Form: Narrative Discourse and Historical Representation, Baltimore, Johns Hopkins University Press, 1987. In the national musicology the question of formal analysis and possibilities of its different interpretatons or different language translations of the same formal musicological analysis into the language of music history has been shown, for example, in: Valentina Ra- 
forms of analysis and interpretation, especially the meaning of music works, are such a kind of self-reflection, critical preoccupation of musicology with its own means, i.e. effects and music itself.

Another meaning of the term 'critical potential' of musicology refers to the fact that the critical ability of musicology is wider than the mentioned one, while the term 'critical theory' no longer has to, as it used to, refer only to the work of the Frankfurt School. Today it is possible to talk in the plural about critical theories as a comprehensive critique of the social order. Musicology, as it has been well known for three decades, ${ }^{12}$ does not have to deal with music alone, remaining within the limits of music itself, but can show how music is set in the world, or in a wide context of diverse social groups, and what effects music can have in this context. There will be a little more about this in this text.

Various and numerous critical theories ${ }^{13}$ became, says Razmig Keuscheyan, especially topical in the 1990s due to the defeat of former rebel social movements that were aimed at the emancipation of the subject. ${ }^{14}$ "It all starts with one defeat," writes Keuscheyan. "Whoever wants to understand the nature of contemporary critical thought must take this statement as a starting point." 15 With this, Keuscheyan refers to the fact that numerous critical discourses were created or strengthened at the moment when a new political cycle symbolically appeared in the world with the demolition of the Berlin Wall in 1989. Whether

doman, Elementi impresionističkog stila u srpskoj muzici prve polovine XX veka, magistarska teza, (rukopis), Katedra za muzikologiju i etnomuzikologiju, Fakultet muzičke umetnosti, Beograd, 2006.

12 Under the condition that the following books, for example, are taken as a symbolic turning point in musicology: Susan McClary, and Richard Leppert, eds., Music and Society: The Politics of Composition, Performance and Reception, Cambridge - New York, Cambridge University Press, 1987; Rose Rosengard Subotnik, Deconstructive Variations: Music and Reason in Western Society, Minneapolis, University of Minnesota Press, 1996 and others.

13 For many theories that Razmig Keucheyan names as "critical theories" Miško Šuvaković uses the term "post critical theory" or "anti-critical theory". According to such a division, Šuvaković argues that not all poststructuralist theories are "revolutionary, interventionist or emancipatory practices because they do not advocate for critical intervention and transformation of society and culture", while some theories, post-critical theories or anti-critical theory have changed their role over time. See: Miško Šuvaković, „Kritička teorija“, in: Pojmovnik teorije umetnosti, op. cit., 386-387.

14 At that time, as it has been said, these critical theories became especially actual, though they originated much earlier, during the $60 \mathrm{~s}, 70 \mathrm{~s}$ and $80 \mathrm{~s}$ of the 20 th century. The Thesis on Defeat is not the original Keucheyan's thesis. It is obvious to all scientists (and not only to scientists), and it is mentioned in many scientific papers, although not as a foundation around which the whole construction of a scientific piece is built, as is the case in Keucheyan's work.

15 Razmig Keucheyan, op. cit. 19. 
this demolition symbolically marked the defeat of the May rebellion of 1968, or the defeat of those ideas that failed to prevent the outbreak of the Great War in 1914 , or the defeat of the ideas which concieved modernism that began at the moment of the French Revolution of 1789, is not as important in this text ${ }^{16}$ as Keucheyan's conclusion saying that "critical theories develop in circumstances marked by the defeat of the left wing striving for the transformation of society."

Being so, one cannot forget the fact that the recovery from the defeat and the transformation of a society can be more easily and effectively imagined and explored from political activism, political philosophy, from economic or legal sciences, critical instead of populist media of information, referential arts, and other areas, than from contemplation over, for example, bar 8 of string quartet ...hold me, neighbor, in this storm... by Aleksandra Vrebalov or some other composition of another music artist from any period of music history. To consider the recovery from defeat and the possibility of transformation of society is not an easy task, but such a review from the music, which is the least referential of all arts, is almost unthinkable.

But what if in that bar 8 of composition ...hold me, neighbor, in this storm... the strange HM exclamation in a string quartet is performed by a man who has left the violin aside and is beginning to play the tapan, or it is performed by a woman playing the tapan, then a listener at a concert of art music faces a marker that points to a world beyond the known "world of art music"? ${ }^{17}$ What if, in one

16 In this short text it is not possible to consider what defeat is in question here but all the time one may have in mind Keucheyan's perception of possible periodization of political cycles or may think of what contemporary critical theory is the answer to which defeat, conditionally speaking.

17 In this text, the expression "the world of art" (artworld) and its derivatives such as "the world of music art" and the like are used in the meaning given by the philosophers Arthur Danto and Richard Wollheim and which are well explained by Šuvaković (in the text „Изузетност и сапостојање: Gesamtkunstwerk, интертекстуално и појам разлике“, y: Мишко Шуваковић (ed.), Изузетност и сапостојање, V Међународни симпозијум Фолклор, Музика, Дело, Београд, Факултет музичке уметности, 1997, 30) by the following words:

Following Arthur Danto it can be said that the artwork is not only what is seen by the eye or heard by the ear, but also our knowledge of the history of art, culture, philosophy, social super-determinants and the mode of perception (the skill of rhetorical placement or transfer of watching, listening, understanding, interpretation, mental, manual or behavioral work). Artwork is not only a mere object (painting, sculpture), a situation (ambience, architecture, scene) or an event (music work, performance, ballet, film), but it always an interpreted object - an object that we see stranded in a network of interpretations. The first interpreter is an artist (according to Richard Willheim) who interprets the structure or order of sounds, words or body acts as an artwork creating it or placing 
performance, imagined or real, that exclamation comes from a harsh-sounding middle-aged man who powerfully performs the instrument on the concert podium, and in another performance it comes from a young man, or an anxious middle-aged or young man, or from an African, Arab, Dutch performer or from a woman or a girl or from a sickening (for example, a mildly cold) woman? And what if a Serb or a Syrian, or a 'Yugonostalgic' Serb or an Albanian or a Bulgarian or an American woman political activist or a Senegalese woman philosopher hears that exclamation? What if that exclamation, which can mean a lot, compromises the expected effect of the protocol of traditional musicology as a scientific discipline by which music is heard-knowing the skill of making music; analyzed-knowing the skill of making music; explained/interpreted by the language (alphabet or speech) to someone who is familiar or not with the knowledge of making a piece of music?

In the traditional-meaning modernist-perception of art and talks about art, that explanation is not even necessary either to the artist or to the aesthete-listener, ${ }^{18}$ because music is an autonomous area with its own laws which are not subject to examination, for example, for veracity or usefulness and the like, but it serves (supposedly) the universal, direct sensuous experience, or more sharply and poetically speaking, this explanation is not necessary because music, as claimed by philosopher and musicologist Vladimir Jankélévitch , “... is magic". ${ }^{19}$ Music should not be analyzed, understood or explained because its wisdom does not last for more than an afternoon, ${ }^{20}$ and it does not have to last because, according to Jankélévitch, music is what overwhelms us (despite the fact or precisely because it is short-lived wisdom) with a passionate admiration, music is what subjugates us using unpermitted ploys to suggest, create an illusion, deceive. ${ }^{21}$

Yet, how can we think, when we want or like or have to think, about that HM exclamation, after something has been suggested to us, to our senses? The traditional (modernist) musicology, despite the aforementioned artist and aesthete-listener, counts on the expected effect of its traditional protocol, and the

it in the world of art and art history. All other interpreters participate in that game by producing differences in the effects, meanings, significance and values.

18 Miško Šuvaković has written about this. See: Miško Šuvaković, Epistemologija umetnosti ili O tome kako učiti učenje o umetnosti, Beograd, Orion Art, 2008.

19 Vladimir Jankélévitch, La Musique et l'Ineffable, Paris. Armand Colin, 1961. (Vladimir Jankelevič, Muzika i neizrecivo, prev. Jelena Jelić, Novi Sad, Književna zajednica Novog Sada, 1987.)

20 Ibid, 138.

21 Ibid, 28. 
expected effect is to ensure that 'almost conventional continuum between a creator, the creation of work, work, and the reception of work and potential discourses on artistic work', which Miško Šuvaković talks about in the Epistemology of Art. ${ }^{22}$ When such an expected effect is missed because musicology has faced a single HM for which there are no means by which it will be analyzed and explained, the creator of the work, the music work and the listener can simply remain connected only by 'magic,' 'affect,' 'sensuous sensation'. ${ }^{23}$

But the composition has the title ...hold me, neighbor, in this storm... and the listener, who concentrates to hear only the sound, surrendering to the 'skill' of music and exclamation 'to be likeable', and despite the fact that the sound is 'passionately skillful' so that its various 'puzzles' subdue the listener, yet he knows, as it is pre-suggested to him, that the sound of the exclamation means something longer than 'an afternoon'. What if the HM exclamation suggests to the listener - any listener, it means to a listener who is a political activist or a philosopher or a listener who is a taxpayer who has to pay for a piece of music or a listener performer who needs to consider why to play a particular piece of music, or a musicologist who should write arguments about the significance and meaning of this exclamation, and others - something that is aggressive or something that is powerless, or something that is offensive to someone, or suggest a whole range of options that can be fulfilled from performance to performance or only in the imagination of a music score reader? ${ }^{24}$ When, along with this exclamation, the listener, in other bars, also hears other sounds that clearly mean something (the sound of another archaic instrument - the gusle, besides the aforementioned tapan, mixed with the sounds of classic string instruments, the sound of church bells, stomping the feet on the floor, and other), regardless whether he recognizes them as easily understandable, extremely simplified stereotypes or not, he, in fact, enters the sphere of listening to the work that requires the pursuit of new means other than the immediate sensuous experience. Expressed in Jankélévitch words, in addition to the sensuous submission to the magic of music, the listener must also understand such music and reach for its conceptualization.

\footnotetext{
22 Miško Šuvaković, op. cit.

23 Any phrase used by philosophers and musicians thinking that music does not have to be understood, and that it is enough to feel it directly with the senses, can be used here.

24 About the interpretation of the piece ...hold me, neighbor, in this storm... from the point of view of the politics of identity and logic of liberal capitalism in the context of musical creativity, see: Валентина Радоман, „Политика идентитета, музика и говор о музици у доба глобализације“, Музикологија, 2012, 12: http:/www.doiserbia.nb.rs/img/doi/14509814/2012/1450-98141200006R.pdf
} 
The semiotics of music, as a musicological and musical-theoretical scientific field, created by the appreciation of the scope of linguistics, which precisely deals with the meaning of music, in its first steps, and in some of the most influential works of today, ${ }^{25}$ has remained / remains deeply bound to formalistic analysis and aesthetics, and perceives the meaning of music when it is clear that some musical 'solutions' (from the simplest choice of timbre, certain intervals or motives, articulations, and the like, to more complex musical creations) have eventually become conventions, artificial agreements in the world of music that these or similar musical 'solutions' represent / mean something specific to a certain community of listeners which also belongs to the world of music, because it is more or less familiar with the norms of this world. As long as the new meanings of music, such as this unusual HM, occur in the context of well-known musical norms, i.e. at least in the hints of conventional musical structure, musicology and music theory, that is, music semiotics can find a way to interpret a new musical signifier as an emerging convention and put it in traditional analytical and interpretative frameworks.

But when it is impossible to do so, then, the musical semiotics and other potential analytical and interpretive musicological discourses need to reach out for new concepts, often for those that are devised to deal with problems or dilemmas or aporias that do not belong to the world of art.

It is especially interesting that in quite opposite cases - when it seems that the significance of a musical signifier or order has, over time, acquired the characteristic of something immediately understandable, and therefore 'natural', by reaching out for new concepts and new angles of consideration, this supposedly natural meaning can be questioned.

So, for example, when the literary theorist Edward Said expressed astonishment after discovering the fact that most of the British or French writers of the 19th and 20th centuries, whom he had always admired, actually supported in their prose works - perhaps only respecting the usual conventions of making a literary work, rather than with deliberate intention - the political ideology of racism, actually, expressed astonishment over the fact that some of the meanings of a reference art, literature, were accepted as 'knowledge' because, over time, they had become so common and conventional that they began to act as 'natural' or became 'invisible' because they were so implicit. ${ }^{26}$ Many of these 'natural' meanings in literature hid horrible opposites - such as the mentioned racist ideology - that were discovered when these meanings were subjected to different, new analytical methodologies and conceptual means of research.

25 For example in the works of Robert S. Hatten.

26 Edward Said, Culture and Imperialism, op. cit. 
This was the case when the concept of the Other which, according to certain interpretations, originated from the ecclesiastic discourse, in the speeches of Pope Pius II during the 15 th century, ${ }^{27}$ was accepted in the scientific discourse. In his official church speeches, in a specific narrative process, the Pope made a clear boundary between 'We,' thinking of Christians and Europeans and 'They,' 'The Other,' thinking of Muslims, Ottoman Turks as absolute enemies who, after the conquest of Constantinople, could have conquered Rome. ${ }^{28}$ In the scientific discourse, this division "We - Other", which could include various representatives of 'Us' and 'Other', became especially topical in the domain of psychology during the 19th century, and was applied in works by German authors under the name Völkerpsychologie. During the $20^{\text {th }}$ century, however, this division became important in other scientific disciplines such as, for example, comparative literature. Then it was used in a comparative sub-discipline, the so-called Imagology, for the purpose of exploring the ways in which some nations 'see' / perceive / describe in literature other nations. So, in 1978 Edward Said wrote a book, now globally famous and assailed, Orientalism, in which he exposed to a new angle of observation and criticism the orientalist discourse, the way that Western nations see, describe, not only in literary prose, but in all texts (media, artistic or scientific), discuss in political reports, paint, extol in canonical poetry, and so on, nations in the East, in the so-called Orient. Musicology is just one of many scientific disciplines that have recognized the significance of Said's discovery which was deeply political.

If attention is now returned to the HM exclamation, it can be noticed that imagology in this case opens the possibility for all listeners, who know the concepts and methods of imagology, to rationally emerge from the frame / experience of the sensuous perception of music only. Similarly, imagology in this case provides an opportunity for musicology to emerge from its autonomous position, from the kind of analysis of the music score or sound by which it would be determined that in the first sentence of the string quartet ...hold me, neighbor, in this storm... a melody line is exposed in the part of the gusle, which is in the second sentence accompanied by the melodic-rhythmic motif of the tapan, so that these two sentences together could make a musical period. Imagology in this case provides musicology with the possibility to talk about issues that are political, which, for example, concern the relationships between those individuals-representatives of the communities playing the gusle, those playing the tapan

\footnotetext{
27 More about it: Tomaž Mastnak, Evropa: med evolucijo in evtanazijo. Ljubljana, Studia humanitatis, Apes 8, 1998. (Tomaž Mastnak, Evropa; Istorija političkog pojma, prev. Milan Đorđević i Dušan Đorđević Mileusnić, Beograd, Beogradski krug, 2007.)

28 Ibid, 55-69.
} 
and those playing classic string instruments, instead of with pseudo-tautological repetition and verbalization of what is written in notes. ${ }^{29}$

But why would musicology, and for whom, except for its own needs, for the self-examination of its methods, deal with it at all, when political issues are the domain of political activism, state policy or political philosophy? One of the known answers is because it is an immanent feature of music art itself. Because it has always been a feature of art, of creation, and all other human practices. Or, for example, because, according to the French philosopher Jacques Rancière, 'political' and music (and other arts) share one common feature - the power to redistribute the sensible in public life, the redistribution of what and who can be heard, seen, felt in public. ${ }^{30}$ But, according to Mirjana Veselinović-Hofman, some perceptions of works of art do not have to be socially, ideologically or scientifically acceptable at all times in history. ${ }^{31}$ Susan McClary reviewed the question: why was it once considered blasphemous to talk about Bach's music in the context of the politics of his time just like in 1950 and $1985 ?^{32}$ The answer is simple at first sight. At one point in history, in the 18th century, or even since the time of ancient Greece, according to McClary, the ideology of the autonomy of art excluded not only Bach's but the whole art from the field of public speaking about society. ${ }^{33}$ Thus, the musicology remained closed in the bar 8 of the mentioned composition or any other part of any other musical piece.

But the 'ideology' or 'view' of musicology - which are two more essential concepts of critical theory - as a scientific discipline that in certain periods of history with its results must remain in the autonomous world of art separated from other spheres of society (for example, from the political sphere) today is,

29 It is already said in footnote 11 that what is written in the notes and then analyzed and translated into the narrative of music history does not coincide, although it is a scientific goal to leave such an impression.

30 Jacques Rancière, Le Partage du sensible: Esthétique et politique, Paris, La fabrique, 2000. (Žak Ransijer, Sudbina slika; Podela čulnog: estetika i politika, prev. Olja Petronić, Beograd, Centar za medije i komunikacije, Fakultet za medije i komunikacije, Univerzitet Singidunum, 2013; Jacques Rancière, „Raspodjela osjetilnog - estetika i politika”, prev. Leonardo Kovačević, Up\&Underground, 2006, 09/10)

31 Mirjana Veselinović-Hofman, "The Position of an Object of Art in an Interdisciplinary Scientific Environment: Questions of Interpretation”, Зборник Матице српске за сиенску уметност и музику бр. 41, 2009, 76.

32 Susan McClary, "The blasphemy of talking politics during Bach Year", in: Richard Leppert and Susan McClary (Eds.) Music and Society: The Politics of Composition, Performance and Reception, Cambridge - New York - Melbourne, Cambridge University Press, 1996 [1987], 13-62.

33 Susan McClary claims that autonomy dates from Pythagorean times. Op. cit, 15. 
if we bear in mind the statement said by Mirjana Veselinović-Hofman, and the mentioned question (and answer) of Susan McClary, only one of the possible, permissible, acceptable ideologies, one of the possible perceptions of musicology. A different ideology is the one that draws both art and talking about art out of the framework of their (common) autonomy and places them, for example, in the world of turmoil, contradictory ideas, proposals, demands from various spheres of life, to transform societies according to needs and the rights of humans, animals, the whole of nature, instead of, for example, according to the dictation of today's capital and the logic of the consumer society and the society of exploitation. It may be argued that today it is possible and acceptable for every musicologist (an ordinary listener or a musical score reader) to respond, in accordance with their knowledge, the type and quality of education they have, the social class or a social group they belong to, the style of life they lead, the political and ethical values they advocate, etc., to the ideology that corresponds to the corpus of their intellectual and sensual ranges, to the ideology that interpellates them, stirs their mind, as claimed by Althusser, or their body, as argued by Foucault. ${ }^{34}$

In that case, some musicologists will be challenged by the ideologies of art autonomy and 'art for the sake of art' and will have the need, as well as the right to define in their works the mentioned HM exclamation as well as the sounds of the gusle, tapans, church bells, the voice of the muezzin, stomping the feet on the floor and similar, as enriching the sound colors of the traditional, artistic string ensemble. In such a speech, they would be obliged to find novelties in the treatment of the traditional form of String Quartet, which would normally be attributed to the creativity of artists and changes in musical forms during its history which are immanent to music art. The title of the composition could be interpreted in a universal context, as a typically artistic, humane call to join $W e$ and the Other and the musical diversities that are the symbols of We and Other - the sounds of archaic and modern instruments, as well as the sounds-symbols of different religions, into one utopian whole, typically artistic, transcendental.

Being interpellated by the ideology of feminism, after applying the same traditional formal analysis or some other kind of analysis, other musicologists would, for example, notice that the archaic instruments have been added to the String Quartet, which was originally a male ensemble, because even in the 19th century, it was still inappropriate for women to play string instruments thus impairing their posture, getting bruises on the body from the attachment of the

34 Louis Althusser, «Ideologie et appareils idéologiques d'État (notes pour une recherche)», La Pensée no 151, 1970. (Luj Altiser, Ideologija i državni ideološki aparati /beleške za istraživanje/, prev. Andrija Filipović, Loznica, Karpos, 2009, 64); 
violin to the neck and the like. They would notice that those selected archaic instruments were also traditionally performed by men, the least for the sake of playing, but more to sing along about the wars they or their ancestors waged, or to produce, by the power and the sound of these instruments, noise, signals, mostly warlike. Feminist musicologists would notice the patriarchal sound of the composition ...hold me, neighbor, in this storm... and consider the question of whether this patriarchal sound is being interestingly destabilized, compromised when the composition is performed by women or, on the contrary, thus even more easily perceived. In the latter case, they would ask the question why the woman composer insists on the sound that is the symbol of the patriarchy.

Led by the research of postcolonial scientists and the terminology they use, the third group of musicologists could, for example, see in the string quartet ...hold me, neighbor, in this storm... the insisting on 'exotic,' 'uncivilized,' 'primitive' sound of archaic, warlike instruments of a particular area (recognizable or not), by confronting with the sound of instruments on which art music is performed and putting that archaic instrument's sound, as well as the sound of $\mathrm{HM}$ and A exclamation, and stomping the feet on the floor, with assigned performance signifiers: groan, like barking, very dramatic, fierce, into the institutions of the original bourgeois concert halls. The 'exotics', after the same formal analysis that would be carried out by the musicologists, would be challenged by other ideologies, interpreted as an artistic subversion of the world of art or as the exploitation of the so-called exotics in the global market that sells it as the most easily sold product.

It seems that the constitution of the world in which we live today enables musicologists to be more aware of the diversity of ideological positions they can take in interpreting music. However, this possibility is not used by all musicologists. Some musicologists consciously pretend not to understand the opportunity that has been available to them for decades. In this regard it is interesting that Charles Rosen, a prominent musicologist and pianist, once "closed his eyes". In 1994 when Rosen and Lawrence Kramer had a brief, but sharp, correspondence about the critique that Rosen addressed to Kramer and other representatives of the New Musicology, Rosen primarily pointed out the alleged mistakes in the formal analysis he found in the works of the representatives of the New Musicology, as if such mistakes did not exist in the works of the authors who advocated the same ideology of autonomy of music as Charles Rosen. For the sake of intellectual kindness Rosen praised the search for new, contextual interpretations of music to which the representatives of 'New Musicology' were devoted, but claimed that, in his opinion, one of the most important representatives among them, composer Lawrence Kramer, did not have the piano playing experience and, therefore, was not sufficiently 'aurally sensitive' to certain, 
particularly important, details in Beethoven's music he wrote about. Kramer drew Rosen's attention to the fact that Rose's "Piano experience" was his last refuge from which he could defend the ideology that had been denied by the development of society and time. He criticized his claims that the experience of listening is fixed, unchanging, that is based on a binary opposition: Right as True vs. Wrong, instead of accepting the fact that music actually requires a lot of 'discontinuous, fragmentary experience' that includes thinking, memory, desire of variable intensities. And all of this equally applies to listening, performing or thinking about music. On the one hand, in the correspondence between Rosen and Kramer there was a controversy regarding which ideology (in the modern complex meaning of this concept) a contemporary musicologist can talk from and for whom. Rosen began his text with an unusual claim: "Almost everyone agrees that performing and listening to music are primary activities; writing about music is secondary, parasitical. Ideally, musicologists ought to write for listeners and performers. In real life, they write for other musicologists. Because they have to." As an excellent musicologist and not so much appreciated pianist, Rosen showed in his own case how one "shoots himself in the foot" when advocating a certain ideology without knowing its complexity. In addition, he titled the text Music à la Mode. Today, almost twenty-five years later, it has turned out that the world has remained basically the same since the symbolic 1989, or the year of the short musical debate, 1994, with many living conditions that have drastically worsened, while only in some details improved. In that respect, it has turned out that Rosen was wrong when he estimated, because of his nostalgia for the world that had long since disappeared, that the changes that touched musicology at the end of the 20th century would not last longer than a passing fashion. Kramer may have erred as much as all those who hoped that the discovery of the opposites of various 'knowledge' imposed by the ideology of the autonomy of art would help raise the awareness that art is not always magic and contribute, as much as possible, to a change in the world we live in for the better. Regardless of the extent to which these hopes have been betrayed or fulfilled now, everybody should know the opposite of art today: art financiers (patrons or taxpayers) and composers who can no longer afford to hide behind the intuition and abstraction, especially not when they cooperate, for example, with oligarchy that uses the arts to conceal their nefarious action, ${ }^{35}$ and performers who choose

35 Only one example of the oligarchical instrumentalization of ideology of art "imagination" and concealment, through art, of oligarchical activities harmful to many social groups will be shown here. It is the example from the UK, Andy Hewitt talks about and Boris Čcučković reviews (Boris Čučković, "Autonomy of Today", TkH, Journal for Performing Arts Theory, 2012, No. 20, 16-21). The selected example from Great Britain is almost the rule in 
which pieces to play, and musicologists and all listeners. Those who want to escape from the 'everyday terrestrial life' through the magic of musical can do it, at the expense of those who will think about different facets of art, with the help of all possible concepts that are available today to art theory. Sometimes the ones fleeing and those thinking, will gladly change places. But this will not change the fact that today, contrary to what Rosen claimed, the primary activities are: performing and listening to music and thinking about music itself and thinking about musical context. And the fact that it is therefore desirable that financiers and composers and performers and listeners, all being members of different ideological, classes, social groups, read good musicological works. A rather cynical response to Rosen's statement that "ideally, musicologists ought to write for listeners and performers. In real life, they write for other musicologists. Because they have to," now would read that today musicologists have to write the least for other musicologists. Being careful not to turn into "Meaning-of-theUniverse merchants" as Terry Eagleton said in another context, ${ }^{36}$ and because of

many countries today. The part of the text in the footnote is taken from the book: Valentina Radoman, Muzika, Politika, Užitak: Funkcije politike i ideologije u muzičkom modernizmu, Beograd, Orion Art, 2018, 19-20:

So, for example, Andy Hewitt identifies three ways in which (autonomous) art has been instrumentalized in the United Kingdom today, or was during the reign of the Labor Party from 1997 to 2010. The same kind of art instrumentalization can be noticed in other countries as well. The first method of instrumentalization implies introducing art into the public space so as to encourage artistic problematization of all issues that would contribute to supporting the development of civil society as a democratic society of public debate and negotiations between social groups. Another use of art for state purposes refers to the treatment of art as an auxiliary tool in "urban regeneration" and "re-branding" of post-industrial cities, while the third form of instrumentalization of socalled autonomous arts implies the participation of "economically marginalized" citizens in the world of art, in order to boost their rise on the social ladder. However, Hewitt notes, while autonomous art in the United Kingdom of the mentioned period served to produce the impression of positive social change, state policy actually implemented the privatization of the public sector, reduced the transparency of the rule and deepened social divisions (Andy Hewitt, 2012. Art and counter-publics in Third Way Cultural Policy, PhD dissertation, University of the Arts London, http://ualresearchonline.arts. ac.uk/5679/).

Thus, art had, in fact, the opposite role in society than the one which appeared on the surface, so that with its allegedly autonomous status and the newly acquired role of mediators in society-which abolished autonomous status in a complicated way-contributed to the real destruction of the public sphere as a place of communication between citizens and the state.

36 Terry Eagleton, After Theory, London, Penguin Books, 2003. (Terry Eagleton, Što nakon teorije?, prev. Darko Polsek, Zagreb, Algoritam, 2005, 75.) 
the development of their musicological competences, now musicologists have to read books on philosophy, political philosophy, political geography, sociology, anthropology, literary theory, art theory, psychoanalytic theory, and they will certainly devote the time left to reading musicological books. But only the best ones, the authors of which can equally well describe a way of creating a musical work superbly using formal or some better musical analysis, as well as to interprete the meaning and the purpose of these musical works from the ideologies from which they are called out, in the context of the world they live in.

It seems that the time has come in which clever, contextually thinking and interdisciplinary prone musicologists want / do more good to the world than many artists, the alleged creators of magic, but in fact, very often the victims of consumer society and the society of exploitation.

Table No. 1: A selection of concepts in musicology which can be redefined, and concepts of the various scientific disciplines or fields which can be used in musicology.

\begin{tabular}{|c|c|c|c|c|}
\hline Musicology & Literary Theory & $\begin{array}{l}\text { History of Art and } \\
\text { Art Theory }\end{array}$ & $\begin{array}{l}\text { Post-colonial } \\
\text { studies }\end{array}$ & $\begin{array}{l}\text { Critical Social } \\
\text { Theory }\end{array}$ \\
\hline A castrato & Author & Acritical critique & Ambivalence & Anti-globalization \\
\hline Absolute music & Authorial intent & $\begin{array}{l}\text { Agony of } \\
\text { modernism }\end{array}$ & Affect & Bourgeoisie \\
\hline $\begin{array}{l}\text { Authentic } \\
\text { performance of } \\
\text { musical works }\end{array}$ & Canon & Appropriation & $\begin{array}{l}\text { Balkan as a meta- } \\
\text { phor }\end{array}$ & Capital \\
\hline Autonomy of music & Enemy Other & Art as a Commodity & Canon & Class \\
\hline $\begin{array}{l}\text { Commissioning a } \\
\text { music work }\end{array}$ & Heteroglossia & $\begin{array}{l}\text { Art as a Truth } \\
\text { Procedure }\end{array}$ & Center / margin & $\begin{array}{l}\text { Collective } \\
\text { memory }\end{array}$ \\
\hline Composer's theory & $\begin{array}{l}\text { Horizons of Expecta- } \\
\text { tion }\end{array}$ & Artworld & Civilized & Diaspora \\
\hline Death of art music & Idiom/Institution & Cynicism tactics & Colonial desire & Elite \\
\hline Emotions (in music) & Intertextuality & Context & Comprador & $\begin{array}{l}\text { Exploitation in } \\
\text { Society }\end{array}$ \\
\hline Festival & Code & $\begin{array}{l}\text { Criticism of } \\
\text { humanism }\end{array}$ & Counter-Discourse & Globalization \\
\hline History (of music) & Context & Discourse & Decolonization & Hegemony \\
\hline Histories of music & Metalanguage & $\begin{array}{l}\text { Discourse of the } \\
\text { Master }\end{array}$ & Eurocentricity & Ideology \\
\hline
\end{tabular}




\begin{tabular}{|c|c|c|c|c|}
\hline $\begin{array}{l}\text { Interpretation } \\
\text { (of formal analysis) }\end{array}$ & Sign & Discourse analysis & Exotic & $\begin{array}{l}\text { Ideological State } \\
\text { Apparatuses }\end{array}$ \\
\hline Music as a culture & $\begin{array}{l}\text { Self-reference in } \\
\text { language }\end{array}$ & Ecological art & $\begin{array}{l}\text { Hegemonic histo- } \\
\text { riography }\end{array}$ & Institution \\
\hline Music Work & $\begin{array}{l}\text { The Limits of } \\
\text { Interpretation }\end{array}$ & Gaze & $\begin{array}{l}\text { Imagining as } \\
\text { knowledge }\end{array}$ & Interpellation \\
\hline Opera & $\begin{array}{l}\text { The Pleasure of the } \\
\text { Text }\end{array}$ & Hybrid arts & $\begin{array}{l}\text { Imagining the Bal- } \\
\text { kans }\end{array}$ & Modernization \\
\hline Originality & Thick Description & Iconology & Imperialism & Multiculturalism \\
\hline $\begin{array}{l}\text { Performativity of } \\
\text { music works }\end{array}$ & Narrative & Kitsch & Liminality & Nationalism \\
\hline Perception of music & Reception & Manifest & Modernization & Oligarchy \\
\hline Popular music & Referentiality & Memory & Orientalism & $\begin{array}{l}\text { Post-industrial } \\
\text { society }\end{array}$ \\
\hline (Public) concert & Signified & Performance Art & Post-colonial body & $\begin{array}{l}\text { Repressive State } \\
\text { Apparatus }\end{array}$ \\
\hline Semiotics of voice & Signified & Polygenre & Primitive & Self-stereotyping \\
\hline $\begin{array}{l}\text { Weak concept of } \\
\text { modern }\end{array}$ & Signifier & Post-history & Racial Other & Social groups \\
\hline $\begin{array}{l}\text { The Beautiful in } \\
\text { Music }\end{array}$ & Style & Political Art & Stigma & Social mobility \\
\hline $\begin{array}{l}\text { The ideology of } \\
\text { voice (typology of } \\
\text { opera voices) }\end{array}$ & $\begin{array}{l}\text { Text (From Work to } \\
\text { Text) }\end{array}$ & Radical Modernism & Subaltern & Space \\
\hline $\begin{array}{l}\text { Total work of art } \\
\text { /Gesamtkunstwerk }\end{array}$ & $\begin{array}{l}\text { The Anxiety of } \\
\text { Influence }\end{array}$ & $\begin{array}{l}\text { Representation } \\
\text { (arts) }\end{array}$ & The idea of Europe & Stereotype \\
\hline Virtuosity & The Open Work & The End of Art & Trauma & Utopia \\
\hline
\end{tabular}


Table No. 2: A selection of concepts from different scientific disciplines or fields that can be used in musicology.

\begin{tabular}{|c|c|c|c|c|}
\hline Philosophy & $\begin{array}{l}\text { Gender Studies - } \\
\text { Feminism }\end{array}$ & Cultural Studies & Body Studies & $\begin{array}{l}\text { Psychoanalytic } \\
\text { theory }\end{array}$ \\
\hline Artworld & $\begin{array}{l}\text { Ahetestic Formalism } \\
\text { is Political }\end{array}$ & Active consumer & Artist's body & Acoustic mirror \\
\hline Aura & $\begin{array}{l}\text { Construction of } \\
\text { female hysteria }\end{array}$ & Alternative cultures & Body & Anti-Oedipus \\
\hline Authenticity & Desubjectification & Anti-elitism & Body and privacy & Big Other \\
\hline $\begin{array}{l}\text { Body without } \\
\text { Organs }\end{array}$ & "Domestic" Art & $\begin{array}{l}\text { Commercialized } \\
\text { culture }\end{array}$ & Body disabilities & Desire \\
\hline $\begin{array}{l}\text { Capitalism and } \\
\text { Schizophrenia }\end{array}$ & Dominant fiction & Consumer culture & Body in culture & $\begin{array}{l}\text { Discourse of the } \\
\text { Analyst }\end{array}$ \\
\hline Deconstruction & Exclusion policy & $\begin{array}{l}\text { Contingency of } \\
\text { meaning }\end{array}$ & $\begin{array}{l}\text { Body of art } \\
\text { performer }\end{array}$ & $\begin{array}{l}\text { Discourse of the } \\
\text { Hysteric }\end{array}$ \\
\hline Deterritorialization & Femininity & Cultural policy & Childhood & $\begin{array}{l}\text { Discourse of the } \\
\text { Master }\end{array}$ \\
\hline Dissemination & $\begin{array}{l}\text { Feminist strategy of } \\
\text { inclusion }\end{array}$ & Cultural populism & Cyborg & $\begin{array}{l}\text { Discourse of the } \\
\text { University }\end{array}$ \\
\hline Discourse & (Female) Other & $\begin{array}{l}\text { Culture as a } \\
\text { political ideology }\end{array}$ & Death & Ego \\
\hline Empire & $\begin{array}{l}\text { Fundamental } \\
\text { unrecognition }\end{array}$ & $\begin{array}{l}\text { Culture as } \\
\text { commodity }\end{array}$ & Docile bodies & Fetish \\
\hline Event & Identity & $\begin{array}{l}\text { Culture of a period } \\
\text { (or structure of } \\
\text { feeling of a period) }\end{array}$ & Emotion & Gaze \\
\hline $\begin{array}{l}\text { Ecstasy of } \\
\text { communications }\end{array}$ & Inner Patriarchate & Decoding & Gaze / Sighting & Hysteria \\
\hline Meta-politics & Masculinity & Dominant values & Generation & $I d$ \\
\hline Mimesis & Men as Culture & Domination & Gesture & Identity \\
\hline Multitude & Patriarchate & Generation & Hearing & Imaginary order \\
\hline Order of discourse & $\begin{array}{l}\text { Perfect visibility of } \\
\text { women }\end{array}$ & Gothic fantasy & Mental illness & Jouissance \\
\hline Policy & Posthuman & Hegemon code & Old age & Mirror stage \\
\hline Political & Private sphere & Inequality & Pain & Objet petit a \\
\hline Politics & Public sphere & Intellectual field & Power & Phantasm \\
\hline Power & Sacrifice & Minority discourses & Remembering & Real \\
\hline
\end{tabular}




\begin{tabular}{|l|l|l|l|l|}
\hline Simulacra & Subject & Popular culture & Sense & $\begin{array}{l}\text { Social production } \\
\text { of Oedipus }\end{array}$ \\
\hline Soul & $\begin{array}{l}\text { The Death of a } \\
\text { "Woman" }\end{array}$ & Postculture & Sexuality & Symbolic order \\
\hline Space & $\begin{array}{l}\text { The private (per- } \\
\text { sonal) is political }\end{array}$ & $\begin{array}{l}\text { Procedures of } \\
\text { everyday creativity }\end{array}$ & Sounds of the body & Scopophilia \\
\hline Subject & $\begin{array}{l}\text { Transnational } \\
\text { femininity }\end{array}$ & $\begin{array}{l}\text { Social practice as a } \\
\text { culture }\end{array}$ & Speech & Subject \\
\hline Text & Women as Nature & $\begin{array}{l}\text { Society of the } \\
\text { spectacle }\end{array}$ & Stigma & Sublimation \\
\hline Trace & $\begin{array}{l}\text { Women's Right to } \\
\text { Education }\end{array}$ & $\begin{array}{l}\text { Tastes of different } \\
\text { social classes }\end{array}$ & Voice & $\begin{array}{l}\text { Symptom/Sinth- } \\
\text { ome }\end{array}$ \\
\hline
\end{tabular}

\section{Works cited}

Eagleton, Terry: Literary Theory: An Introduction. Oxford: Blackwell, 1983. (Terry Eagleton: Književna teorija. Prev. Mia Pervan-Plavec. Zagreb: Liber, 1987)

Eagleton, Terry: After Theory. London: Penguin Books, 2003. (Terry Eagleton: Što nakon teorije?, prev. Darko Polšek, Zagreb: Algoritam, 2005)

Илић, Ивана: Епистемологија савремене музичке анализе, докторска дисертација (рукопис), Катедра за музикологију, Београд: Факултет музичке уметности, 2016.

Jankélévitch, Vladimir: La Musique et l'Ineffable. Paris: Armand Colin, 1961. (Vladimir Jankelevič: Muzika i neizrecivo. Prev. Jelena Jelić. Novi Sad: Književna zajednica Novog Sada, 1987.

Keucheyan, Razmig: Hémisphère gauche: Cartographie des nouvelles pensées critiques. Paris: La Découverte, 2013. (Razmig Kešejan: Leva hemisfera; Kartografija novih kritičkih mišljenja. Prev. Olja Petronić. Beograd: Fakultet za medije i komunikacije, Univerzitet Singidunum, 2016)

Kramer, Lawrence: In response to "Music à la Mode". The New York Review of Books, June 23, 1994.

Mastnak, Tomaž: Evropa: med evolucijo in evtanazijo. Ljubljana: Studia humanitatis, Apes 8, 1998. (Tomaž Mastnak: Evropa; Istorija političkog pojma. Prev. Milan Đorđević i Dušan Đorđević Mileusnić. Beograd: Beogradski krug, 2007)

McClary, Susan: "The blasphemy of talking politics during Bach Year”, in: Richard Leppert and Susan McClary (Eds.) Music and Society: The Politics of Composition, Performance and Reception. Cambridge - New York - Melbourne: Cambridge University Press, 1996.

Said, Edward W.: Culture and imperialism. New York: Vintage Books, 1993. (Edvard Said: Kultura i imperijalizam. Prev. Vesna Bogojević. Beograd: Čigoja štampa/Beogradski krug, 2002) 
Rancière, Jacques: Le Partage du sensible: Esthétique et politique. Paris: La fabrique, 2000. (Žak Ransijer: Sudbina slika; Podela čulnog: estetika i politika. Prev. Olja Petronić. Beograd: Centar za medije i komunikacije, Fakultet za medije i komunikacije, Univerzitet Singidunum, 2013; Jacques Rancière: „Raspodjela osjetilnog - estetika i politika”. Prev. Leonardo Kovačević. Up\&Underground, 2006, 09/10)

Radoman, Valentina: Muzika, Politika, Užitak: Funkcije politike i ideologije u muzičkom modernizmu. Beograd: Orion Art, 2018.

Rosen, Charles: "Music à la Mode". The New York Review of Books, june 23, 1994.

Шуваковић, Мишко: „Изузетност и сапостојање: Gesamtkunstwerk, интертекстуално и појам разлике“. Изузетност и сапостојање, V Међународни симпозијум Фолклор, Музика, Дело. Београд: Факултет музичке уметности, 1997, 30-39.

Šuvaković, Miško: Epistemologija umetnosti ili O tome kako učiti učenje o umetnosti. Beograd: Orion Art, 2008.

Šuvaković, Miško: Pojmovnik teorije umetnosti. Beograd: Orion Art, 2011.

Веселиновић-Хофман, Мирјана: „Контекстуалност музикологије“. Нови Звук, специјално издање Постструктуралистичка наука о музици. Београд, 1998, $13-20$.

Веселиновић-Хофман, Мирјана: „Позиција уметничког објекта у интердисциплинарном научном окружењу: питања интерпретације“. Зборник Матице српске за сиенску уметност и музику, 2009, 41, 67-77.

\section{Summary}

In 1994 there was a brief discussion between Charles Rosen and Lawrence Kramer on the perspectives of musicology in The New York Review of Books magazine. Charles Rosen advocated the idea of music autonomy and claimed that a pianist could better hear music than those musicologists who were not active players of an instrument and then a pianist-musicologist could offer his analysis of a musical piece to performers and listeners. He expressed doubts about the 'hearing sensitivity' and musicological analyses of Lawrence Kramer, the composer, who was also one of the most important representatives of the so-called New musicology. By this discredit Rosen actually criticized all those musicologists who, in those years, reached out for new interpretations of music or attempts to exceed the frameworks of formal analysis and formalistic aesthetics. In response to this kind of criticism, Kramer noted that the ideology of music autonomy from which music was heard and interpreted by Charles Rossen, was the ideology of the past, applicable to the music of the 18th and 19th centuries, but that musical experience is much more complex than the moralizing binary division to the right (true) listening and wrong listening.

This paper sets the thesis that today it is possible to use different ideologies of interpretation of musical works in accordance with intellectual, educational, sensuous, class, ethical and all other potentials of the musicologist. It points out the importance of the critical ability of musicology to highlight its own means and methods of music research, but the focus is placed on exploring the critical potential of musicology which is not related to musicology itself, but surpasses its traditional limits. The application of critical 
terms from various critical theories and scientific disciplines in contemporary musicology allows musicologists to do much more subtle analyses and interpretations of musical works than ever before. When such types of analyses and interpretations of a piece of music are successful they can be useful to a much greater number of readers than ever before. Unlike traditional musicology which, according to Charles Rosen, mostly addressed musicologists themselves, and only in ideal cases to performers and listeners, today's interdisciplinary critical musicology, in its good examples, is indispensable to all: the financiers of art (patrons or taxpayers), composers who are often victims of the market today, or are masks used by the oligarchs to hide behind, performers who choose what musical works to play and affirm and how to do it, and all listeners who are not professional musicians, but they need to be informed about different aspects of music art. 
Чланак примљен 30. августа 2018. Чланак прихваћен 5. новембра 2018.

\title{
Валентина Радоман *
}

Универзитет у Новом Саду

Академија уметности

Катедра за музикологију и етномузикологију

\section{НОВА КРИТИЧКА МИШЉЕЊА У МУЗИКОЛОГИЈИ Из којих идеологија говоре савремени музиколози и за кога}

\begin{abstract}
Апстракт: Нова критичка мишљења у музикологији нова су већ најмање тридесет година, па ипак још увек наилазе на отпор многих музиколога или композитора или извођача, који адорновски (Theodor W. Adorno) остају одани идеји да је функција уметности у друштву да буде без функције. Чињеница је, међутим, да је и данас такав став легитиман, исто онолико колико су исправна интердисциплинарна, критички усмерена музиколошка истраживања којима се показује да музика, попут других уметности, иза своје чулне заводљивости често скрива недопустива наличја. Сваки музиколог данас може на основу својих интелектуалних, образовних, чулних, класних, етичких и других потенцијала да изабере позицију из које ће говорити о музици. За разлику од традиционалне музикологије која се, према речима појединих музичара, углавном обраћала самим музиколозима, а само у идеалним случајевима и извођачима и слушаоцима, данашња интердисциплинарна критичка музикологија, у својим добрим примерцима, неопходна је свима: финансијерима уметности (меценама или пореским обвезницима), композиторима који су данас често жртве тржишта, или маске иза којих се скривају олигарси, извођачима који бирају која музичка дела и како ће да свирају и афирмишу, и свим слушаоцима који нису професионални музичари, али имају потребу да буду обавештени о различитим аспектима музичке уметности.
\end{abstract}

Кључне речи: идеологије тумачења музике, идеологије перцепције музике, критичке теорије, критички потенцијал музикологије, савремена музикологија.

Тема овог рада могла би подједнако да 'води дијалог' са темама, односно садржајем оних књига као што је пре пет година објављена књига Hémisphère gauche Cartographie des nouvelles pensées critiques (Лева хемисфера; Картографија нових критичких мишљеља) француског социолога и филозофа, Размига Кешејана (Razmig Keucheyan), ${ }^{1}$ или са садржајем пре тридесет пет година штампане књиге Кьижевна теорија теоретичара књижевности Терија Иглтона (Terry Eagleton) и сличних књига новијег

\footnotetext{
* Ауторкина контакт адреса: vradoman@yahoo.com

${ }^{1}$ Razmig Keucheyan, Hémisphère gauche: Cartographie des nouvelles pensées critiques, Paris, La Découverte, 2013. (Razmig Kešejan, Leva hemisfera; Kartografija novih kritičkih mišljenja, Beograd, Fakultet za medije i komunikacije, Univerzitet Singidunum, 2016)
} 
датума, ${ }^{2}$ или са бројним књигама естетичара и теоретичара уметности попут Мишка Шуваковића и других, ${ }^{3}$ колико и са садржајем оних утицајних књига и текстова из области музикологије, у којима су размотрени или на примерима показани методолошки изазови савремене музикологије и њен критички потенцијал. ${ }^{4}$ Данашње, још шире отварање граница музикологије као научне дисциплине ка другим научним областима, него што је то била она реална отвореност музикологије - ка природним наукама и филологији - са њеног зачетка, ${ }^{5}$ пружа музикологу већ одавно, од 80-их година XX века, прилику да оствари дијалог са ауторима научних радова из широког спектра научних дисциплина и критичких теорија које су у њима створене или примењене. ${ }^{6}$ То широко отварање граница музикологије чини савремену музикологију поприштем најразличитијих, често опречних, контрадикторних мишљења која су у непрестаној, мање или више видљивој, борби за превласт у музикологији или у ширем контексту. Делезовим (Gilles Deleuze) речима, могло би се рећи да је то разматрање неминовне трансформације музикологије, са свим подстицајним критикама, па и неугодним подсмесима, ${ }^{7}$ које су те трансформације током три деценије претрпеле, већ

${ }^{2}$ Terry Eagleton, Literary Theory: An Introduction, University of Minnesota Press, 1983. (Terry Eagleton, Literarna teorija: uvod, prev. Mia Pervan-Plavec, Zagreb, Liber, 1987)

${ }^{3}$ Од бројних књига Мишка Шуваковића, овде је можда довољно поменути капитално дело Pojmovnik teorije umetnosti (Beograd, Orion Art, 2011), у којем је набројано и детаљно објашњено преко хиљаду концепата који чине савремену теорију уметности.

4 Када је реч о музиколошким књигама, можда је довољно напоменути да је све крупнија мултинационална компанија, која је припојила себи многе чувене издавачке куће - издавачка кућа Routledge, почела од 2006. године, у едицији Ashgate Contemporary Thinkers on Critical Musicology поново да објављује одабране књиге водећих музиколога у области критичке музикологије. Међу тим именима су: Роберт П. Морган (Robert P. Morgan), Анегрет Фаузер (Annegret Fauser), Дерек Б. Скот (Derek В. Scott), Ричард Леперт (Richard Leppert), Лоренс Крејмер (Lawrence Kramer), Сузан Меклери (Susan McClary) и др. Видети: https://www.routledge.com/music/series/ACTCMS

У националним оквирима треба се подсетити текста из 1998. године, „Контекстуалност музикологије“ Мирјане Веселиновић-Хофман, у специјалном издању часописа Нови звук које је носило наслов Постструктуралистичка наука о музищи. За разлику од краће, али садржајне и значајне преписке које су о тзв. Новој музикологији водили, између осталих, Лоренс Крејмер, као један од представника Нове музикологије, и Чарлс Розен (Charles Rosen) који је у тексту „Music à la Mode” (The New York Review of Books, june 23, 1994) критиковао Нову музикологију, никаквих (написаних, аргументованих) критика није у националним оквирима било поводом текста „Контекстуалност музикологије“. А у том тексту су на врло смирен начин - за разлику од само четири године раније Розенове приговарајуће реакције и извесне врсте узалудног покушаја да промени ток неминовних трансформација музикологије и Крејмеровог љубазног, али и помало патронизирајућег одговора на критике које су му упућене констатоване промене у савременој музикологији, проузроковане, како је објашњено „деконструктивистичком инхеренцијом музике“, и подржано запажање Роуз Розенгард Суботник, које се и данас показује исправним, да не види ,фаталну контрадикцију између прихватања аутономије [музике], као врсте парадигме за интерпретирање структуре, и одбијања аутономије, као епистемолошке идеологије“.

5 Иако је ту отвореност према другим дисциплинама Гвидо Адлер (Guido Adler) као један од утемељитеља науке о музици, замислио као у будућности потпуну отвореност ка свим дисциплинама које би помогле да се оствари научни задатак расплитања свих друштвених, економских и политичких веза између музике и културе (Guido Adler, „Musik und Wissenschaft“, Akademische Antrittsrede, gehalten am 26. October 1898 an der Universität Wien, Jahrbuch der Musikbibliothek Peters, 5, према: Ивана Илић, Епистемологија савремене музичке анализе, докторска дисертација (рукопис), Катедра за музикологију, Факултет музичке уметности, Београд, 2016, 60).

${ }^{6}$ И посредан дијалог, са књигама аутора, и непосредан, са самим ауторима савременицима - када могу настати и заједнички радови о истој теми, сагледани из углова двеју или више научних дисциплина.

7 Подсмехе упућују, с једне стране, зрели научници који, речима Роберта С. Нелсона из неког другог контекста „суочени са изазовом промене, покушавају да се тој промени одупру реафирмисањем прошлости и апеловањем на повратак стандардима, који се обично дефинишу као стање дотичне 
„уморна мисао“. Упркос томе, та тема још увек, судећи према темама музиколошких симпозијума, докторских дисертација и књига, захтева интелектуалне дебате, и тиме показује да музикологија као дисциплина још увек нема или не жели да има научним консензусом осмишљену стабилну или прихватљиво флуидну платформу, односно процедуре и протоколе савремених истраживања.

Због тога би у овом тексту могло бити речи о једној врсти подсетника, систематичног прегледа различитих струја мишљења које су утицале на музикологију од њеног настанка у XIX веку до данас. Ипак, то је могућно, односно примереније остварити у књизи него у једном кратком тексту. Нарочито би се у том случају могло расправљати о томе шта значи израз 'нова критичка мишљења', а посебно шта у свим својим слојевима носи одредница 'нова'. Јер, проблем 'новог' посебан је теоријски проблем, док је у наслову овог текста та одредница употребљена једноставније, у смислу нечег актуелног - оних критичких мишљења која су већ незаобилазни део интелектуалног стасавања најмлађих генерација научника. ${ }^{8}$ Или, могао би у овом тексту бити направљен избор и преглед најутицајнијих критичких мишљења који су у музикологији пронашли највише одјека и допринели значајним музиколошким увидима до којих тзв. традиционална музикологија својим средствима није могла да допре. Такође, могла би се поставити негативна теза и одабрати примери музиколошких примена различитих критичких теорија, односно њихових концепата којима је, неадекватним преношењем у област говора о музици, музикологија доведена у неугодну позицију; или би се могло говорити о методологији и концептима новооформљених области истраживања, музиколошких, односно трансмузиколошких, попут: студија популарне музике, музичких постколонијалних студија, иконолошких студија, студија рода, студија радија, студија медија и комуникација, студија тела, студија тела у друштвеном контексту и др. Постоји још много могућности за говор о овој, још увек актуелној теми.

Од многобројних могућности, у овом раду је изабран приступ којим се на свега пар концепата (Други и идеологија) који су кључни за одређене критичке теорије, при томе и заједнички за више научних дисциплина, а који музикологији долазе „споља“ -

дисциплине из доба када су они сами били студенти“. С друге стране, подсмехе, не самој музикологији, већ критичким теоријама и примени критичких теорија у различитим научним дисциплинама, упућују научници који немају велики научни утицај какав су стекли аутори о којима се пише, попут Франсоа Кисеа (François Cusset), aутора књиге French Theory; Fuko, Derida, Delez \& Co i preobražaj intelektualnog života u SAD (prev. Olja Petronić, Beograd, Karpos, 2015), а такође и они који су противници критичких теорија, уопштено, и из најразличитијих разлога: зато што заступају другачије политичке идеје од већином постмарксистичких и неомарксистичких идеја које натапају поље постструктуралистичких критичких теорија, зато што се противе појединим дометима или поразима критичких теорија, али их, упркос томе, уопштено сагледавају из негативног угла, зато што критичке теорије, нарочито француску критичку теорију, могу да користе као добро средство за пласирање цинизма без шарма, попут Кристофера Батлера (Christopher Butler) у књизи Postmodernizam; Sasvim kratak uvod (prev. Predrag Mirčetić, Beograd, Službeni glasnik, 2012.) и др.

${ }^{8}$ Средње и старије генерације научника са својим богатим искуствима и хоризонтом на којем се могу видети домети и 'традиционалне' и савремене музикологије ('савремене' у смислу 'данашње' која је неминовно морала да претрпи извесне измене током времена), или различите институције, са својим механизмима чувања 'стабилности' научних дисциплина, имају, за разлику од млађих генерација научника, могућност избора, односно могу да негују још увек амбивалентан однос према трансформацијама музикологије, тиме производећи или негативне или подстицајне тензије између 'традиционалне' и савремене музикологије . 
проверава да ли музикологија данас може да опстане без тих концепата или мора да их преузима, и коме наука о музици данас служи: студентима музике, композиторима, извођачима, слушаоцима, научној заједници, одређеној друштвеној класи или одређеним друштвеним групацијама. Било је тешко у импресивном броју веома инспиративних концепата, које је из различитих дисциплина могућно користити у музикологији, ${ }^{9}$ изабрати неколицину који ће овом приликом бити добри као узори промене музиколошког мишљења од последњих деценија XX века до данас, и показатељи критичког потенцијала музикологије. Па ипак, поменути избор је направљен, иако би и неки други избор био подједнако одговарајућ.

Када се у овом тексту помене 'критички потенцијал', тај израз се, за разлику од његове употребе у многим другим музиколошким радовима, користи у само два значења. ${ }^{10}$ У првом значењу критички потенцијал се односи на могућност, односно обавезу музикологије, да увек изнова и изнова преиспитује своја утврђена средства истраживања музике, остајући при том у домену говора само о музици. Преиспитивање учинака и домета различитих видова формалне анализе, или премештања/превођења резултата формалне анализе изражених хармонским и формалним или структуралним шифрама у писани наратив говорног језика и наратив историје музике, преиспитивање самог наратива историје или теорије музике - њихове фиктивности на пример, ${ }^{11}$ или успостављање нових видова анализе и тумачења, нарочито значења музичких дела, таква су врста саморефлексије, критичке преокупираности музикологије сопственим средствима, односно учинцима, и музиком самом.

У другом значењу, израз „критички потенцијал“ музикологије односи се на чињеницу да је критичка способност музикологије ширих домета од наведеног, док се сам израз „критичка теорија“ више не мора, као некада, односити само на рад Франкфуртске школе. Данас је могућно говорити у множини, о критичким теоријама као о свеобухватној критици друштвеног поретка. А музикологија се, као што је то

\footnotetext{
9 Видети Табеле бр. 1 и бр. 2 у којима је направљен субјективни и обимом текста одређен избор концепата из различитих научних дисциплина. У тим научним дисциплинама наведени концепти су произведени или, у ређим случајевима, само примењени.

${ }^{10}$ При томе се не губи из вида чињеница да се та два значења могу гранати у многобројна друга значења. Али, у овом тексту, ова два значења су изабрана као најважнија, са свешћу о томе да се тиме неминовно губе многе нијансе којима се одликује данашња критичка музикологија у свету. У многим срединама, међутим, питање тих нијанси још није стигло на ред, од решавања других, старих музиколошких проблема.

${ }^{11}$ Питањем тумачења чињеница, у области историје друштва или уметности, у светлу сазнања да су значења учинак врсте наратива којем се прибегава и да због тога дискурс историје друштва или уметности има много више заједничког са фикционалним приповедањем, него што то историчари желе да признају бавили су се, између осталих, Едвард Саид (Edward Said) и Хејден Вајт (Hayden White). Видети, на пример: Edward W. Said, Orientalism, London-New York, Routledge-Kegan Paul, 1978. (Edvard Said, Orijentalizam, prev. Drinka Gojković, Beograd, Biblioteka XX vek, 2000.); Edward W. Said, Culture and Imperialism. New York, Vintage Books, 1993. (Edvard Said, Kultura i imperijalizam, prev. Vesna Bogojević, Beograd, Čigoja štampa/Beogradski krug, 2002); Hayden White, The Content and the Form: Narrative Discourse and Historical Representation, Baltimore, Johns Hopkins University Press, 1987. У музикологији националних оквира, питање формалне анализе и могућности њених различитих интерпретација, односно различитих превођења језика исте формалне музичке анализе у језик историје музике, показано je, на пример, у: Valentina Radoman, Elementi impresionističkog stila u srpskoj muzici prve polovine XX veka, magistarska teza, (rukopis), Katedra za muzikologiju i etnomuzikologiju, Fakultet muzičke umetnosti, Beograd, 2006 .
} 
добро познато већ три деценије, ${ }^{12}$ не мора више бавити музиком самом, остајући у оквирима музике саме, већ може показати како је музика постављена у свет, односно у широки контекст разноликих друштвених групација, и какви све, у том контексту, могу бити учинци музике. О томе ће у овом тексту бити мало више речи.

Различите и бројне критичке теорије ${ }^{13}$ постале су, каже Размиг Кешејан, нарочито актуелне 90-их година XX века услед пораза ранијих бунтовничких друштвених покрета који су за циљ имали еманципацију субјекта. ${ }^{14}$ „Све почиње једним поразом“, пише Кешејан. „Ко год пожели да разуме природу савремених критичких мисли мора да узме ову констатацију као полазну тачку.“15 Кешејан тиме мисли на чињеницу да су бројни критички дискурси настали или ојачали онога тренутка када је у свету симболички наступио нови политички циклус, рушењем Берлинског зида 1989. године. Да ли је то рушење симболички означило пораз мајске побуне из 1968. године, или пораз оних идеја које нису успеле да спрече избијање Великог рата, 1914, или пораз идеја којима је зачет модернизам у тренутку Француске револуције из 1789. године, није толико важно у овом тексту, ${ }^{16}$ колико је битан Кешејанов закључак да се „критичке теорије развијају у околностима обележеним поразом левице која се залаже за трансформацију друштва“.

Када је већ тако, не може се сметнути с ума чињеница да се опоравак од пораза и трансформација друштва сигурно лакше и учинковитије могу замишљати и испитивати из политичког активизма, политичке филозофије, из економских или правних наука, критичких уместо популистичких медија информација, референцијалних уметности, и других области, него из контемплације над, на пример 8. тактом гудачког квартета ...hold me, neighbor, in this storm... (...nригрли ме, суседе, у ово невреме...) Александре Вребалов или неке друге композиције неког другог музичког уметника из било којег периода музичке историје. Разматрати опоравак од пораза и могућност трансформације друштва није нимало лак задатак, а такво разматрање из музике, која је најмање референцијална од свих других уметности, готово је незамисливо.

Али, шта ако се управо у том 8. такту композиције ...hold me, neighbor, in this storm..., када чудан узвик ХМ, у једном гудачком квартету, изводи мушкарац док остављајући за извесно време виолину са стране - почиње да свира тапан, или га

12 Под условом да се као симболичка прекретница у музикологији узму, на пример, књиге: Susan McClary, and Richard Leppert, eds., Music and Society: The politics of composition, performance and reception, Cambridge-New York, Cambridge University Press, 1987; Rose Rosengard Subotnik, Deconstructive Variations: Music and Reason in Western Society, Minneapolis, University of Minnesota Press, 1996. и др.

${ }^{13}$ Мишко Шуваковић за многе теорије које Размиг Кешејан назива „критичким теоријама“, користи одредницу „посткритичка теорија“ или „,антикритичка теорија“. У складу са таквом поделом Шуваковић износи тачну тезу да нису све постструктуралистичке теорије „револуционарне, интервентне или еманципаторске праксе јер се не залажу за критичку интервенцију и преображај друштва и културе“, док су неке теорије, посткритичке теорије или антикритичке теорије временом мењале своју улогу. Видети: Miško Šuvaković, „Kritička teorija“, у: Pojmovnik teorije umetnosti, нав. дело, 386-387.

14 Тада су, као што је речено, те критичке теорије постале нарочито актуелне, иако су настајале много раније, током 60-их, 70-их и 80-их година XX века. Теза о поразу није оригинална Кешејанова теза. Она је свим научницима (и не само научницима) очигледна, и у многим научним радовима се помиње, мада не као ослонац око којег се гради читаво здање једног научног дела, што је у Кешејановом раду случај.

${ }^{15}$ Razmig Kešejan, нав. дело, 19.

${ }^{16}$ Није могуће у овом кратком тексту разматрати о којем поразу је овде реч, али се све време може имати на уму Кешејаново сагледавање могућих периодизација политичких циклуса, или размишљати о томе које условно речено савремене критичке теорије јесу одговор на који пораз. 
изводи жена свирајући тапан, слушалац на концерту уметничке музике суочава са означитељем који упућује на свет ван познатог „света уметничке музике“? ${ }^{17}$ Шта ако тај узвик у једном извођењу, замишљеном или реалном, долази од грленог средовечног мушкарца извођача који на концертном подијуму снажно удара инструмент, а у другим извођењима од младића, или од анксиозног средовечног мушкарца или анксиозног младића, или од извођача Африканца, Арапина, Холанђанина, од жене или од девојке или од болешљиве (на пример, благо прехлађене) жене? И шта ако тај узвик слуша Србин или Сиријац, или 'југоносталгични' Србин, или Албанац, или Бугарин или Американка политичка активисткиња или Сенегалка филозофкиња? Шта ако се тим узвиком који може означавати много тога доводи у питање очекивани ефекат протокола традиционалне музикологије као научне дисциплине којим се музика чује познавањем умећа израде музичког дела; анализира - познавањем умећа израде музичког дела; и језиком - писмом или говором - објашњава/тумачи некоме ко познаје умеће израде музичког дела или не?

У традиционалном - што значи и модернистичком, поимању уметности и говора о уметности то објашњење није чак ни неопходно ни уметнику ни естети-слушаоцу, ${ }^{18}$ јер је музика аутономна област са својим законитостима које не подлежу провери, на пример, истинитости или корисности и слично, већ служи (наводно) универзалном, непосредном чулном доживљају, или заоштреније, а поетичније речено, то објашњење није неопходно јер је музика, како је тврдио филозоф и музиколог Владимир Јанкелевич (Vladimir Jankélévitch), ,....една чаролија“. ${ }^{19}$ Музику не треба анализирати, разумети или објашњавати јер, њена мудрост не траје дуже од једног поподнева, ${ }^{20}$ и не мора да траје јер, према Јанкелевичу, музика је оно што нас придобија (упркос томе или управо зато - што је краткотрајне мудрости) једном страственом вештином допадања, музика је оно што нас потчињава помоћу сугерисања, опсењивања, обмањивања, недозвољеним смицалицама. ${ }^{21}$

\footnotetext{
17 У овом тексту се израз „свет уметности“ (artworld) и његове изведенице попут „свет уметничке музике“ и сличне, користи у оном значењу које су му дали филозофи Артур Данто (Arthur Danto) и Ричард Волхајм (Richard Wollheim), а који Мишко Шуваковић добро објашњава (у тексту „Изузетност и сапостојање: Gesamtkunstwerk, интертекстуално и појам разлике“, у: Мишко Шуваковић (ур.), Изузетност и сапостојање, V Међународни симпозијум Фолклор, Музика, Дело, Београд, Факултет музичке уметности, 1997, 30) следећим речима:

Следећи Артура Дантоа (Arthur Danto) може се рећи да уметничко дело није само оно што се види оком или чује ухом, већ и наше знање историје уметности, културе, филозофије, друштвених наддетерминенција и модуса перцепције (умећа реторичког смештања или премештања гледања, слушања, разумевања, интерпретирања, менталног, мануелног или бихевиоралног чињења). Уметничко дело није само пуки објект (слика, скулптура), ситуација (амбијент, архитектура, сцена) или догађај (музичко дело, перформанс, балет, филмска представа), већ је увек и интерпретирани објект - објект који видимо узглобљен у мрежи интерпретација. Први интерпретатор је уметник (по Ричарду Волхејму) који објекат или поредак звукова, речи или телесних аката интерпретира као уметничко дело стварајући га или смештајући га у свет уметности и историју уметности. Сви други интерпретатори учествују у тој игри производећи разлике ефеката, значења, смисла и вредности.

${ }^{18}$ О овоме пише и Мишко Шуваковић. Видети: Miško Šuvaković, Epistemologija umetnosti ili O tome kako učiti učenje o umetnosti, Beograd, Orion Art, 2008.

${ }^{19}$ Vladimir Jankélévitch, La Musique et l'Ineffable, Paris. Armand Colin, 1961. (Vladimir Jankelevič, Muzika $i$ neizrecivo, prev. Jelena Jelić, Novi Sad, Književna zajednica Novog Sada, 1987)

${ }^{20}$ Исто, 138.

${ }^{21}$ Исто, 28.
} 
Па ипак, како да мислимо, када желимо или хоћемо или морамо да мислимо, тај узвик ХM, након што нам је, нашим чулима, нешто сугерисао? Традиционална (модернистичка) музикологија, упркос поменутом уметнику и естети-слушаоцу, рачуна на очекивани ефекат свог традиционалног протокола, а тај очекивани ефекат је обезбеђивање оног „готово конвенционалног континуума између ствараоца, стварања дела, дела, рецепције дела и потенцијалних дискурса о уметничком делу“, о којем у књизи Епистемологија уметности говори Мишко Шуваковић. ${ }^{22}$ Када такав очекивани ефекат изостане јер се музикологија суочила са једним ХМ за који нема средства помоћу којих ће га анализирати и објаснити, стваралац дела, музичко дело и слушалац могу једноставно да остану повезани само „чаролијом“, „афектом“, „чулном сензацијом“.23

Али, композиција има наслов ...nригрли ме, суседе, у ово невреме... и слушалац, који се препушта томе да чује само звук, предајући се 'вештини' музике и узвика 'да се допадне', и упркос томе што је тај звук 'страствено вешт' у томе да својим разним 'смицалицама' потчини слушаоца, ипак зна, јер му је унапред сугерисано, да тај звук узвика нешто и значи дуже од 'једног поподнева'. Шта ако тај узвик ХМ сугерише слушаоцу - било којем слушаоцу, што значи слушатељки политичкој активисткињи или филозофкињи или слушаоцу пореском обвезнику који треба да плати музичко дело или слушаоцу извођачу који треба да размисли због чега ће да свира одређено музичко дело, или музикологу који треба да аргументовано напише какво је значење, а какав смисао тог узвика, и другима - нешто што је агресивно или нешто што је немоћно, или нешто што је за неког увредљиво, или сугерише читав спектар могућности које се могу остваривати од извођења до извођења или само у имагинацији читаоца партитуре ${ }^{24}$ Када уз тај узвик слушалац, притом, у другим тактовима чује и друге звуке који очито нешто значе (звук још једног архаичног инструмента - гусала, осим поменутог тапана, помешане са звуцима класичних гудачких инструмената, снимак звука црквених звона, ударање ногама о под и др.), без обзира на то да ли их препознаје као лако разумљиве, крајње поједностављене стереотипе или не, он, заправо, ступа у сферу слушања дела које изискује посезање за новим средствима осим непосредног чулног доживљаја. Осим чулног, Јанкелевичевим речима, потчињавања чаролији музике, слушалац мора такву музику и да разуме, и да посегне за њеном концептуализацијом.

Семиотика музике, као музиколошка и музичко-теоријска научна област настала угледањем на домете лингвистике, а која се управо бави значењем музике, у првим корацима, па и појединим данашњим најутицајнијим радовима, ${ }^{25}$ остајала је/остаје дубоко везана за формалистичку анализу и естетику, а значење музике сагледава онда када је јасно да су нека музичка 'решења' (од најједноставнијег избора тембра, одређених интервала или мотива, артикулације, и слично, до комплекснијих музичких

\footnotetext{
${ }^{22}$ Miško Šuvaković, нав. дело

23 Овде се може употребити било који израз којим се служе филозофи и музичари који сматрају да музика не мора да се разуме, и да је довољно да се она осети непосредно, чулима.

${ }^{24}$ О тумачењу дела ...hold me, neighbor, in this storm... из угла разматрања политике идентитета и логике либералног капитализма у контексту музичког стваралаштва, видети: Валентина Радоман, „Политика идентитета, музика и говор о музици у доба глобализације“, Музикологија, бр. 12, 2012: http://www.doiserbia.nb.rs/img/doi/1450-9814/2012/1450-98141200006R.pdf

${ }^{25}$ На пример, у радовима Роберта Хатена (Robert S. Hatten).
} 
творевина) временом постала конвенције, артифицијелни договори у свету музике, да та или слична музичка 'решења' заступају/значе нешто одређено, одређеној заједници слушалаца која такође припада том свету музике, јер мање или више познаје норме тог света. Докле год се нова значења музике, попут тог неуобичајеног ХМ, јављају у контексту познатих музичких норми, тј. макар у наговештајима конвенционалне музичке структуре, музикологија и музичка теорија, односно музичка семиотика могу да пронађу начин да нови музички означитељ, протумаче као конвенцију у настајању и сместе га у традиционалне аналитичке и интерпретативне оквире.

Али, када је то немогуће учинити, онда и музичка семиотика и други потенцијални аналитички и интерпретативни музиколошки дискурси морају да посегну за новим концептима, често за оним који су смишљени за суочавање са проблемима или дилемама или апоријама, који не припадају свету уметности.

Посебно је занимљиво то што се и у сасвим супротним случајевима - када се чини да је значење неког музичког означитеља или поретка временом добило својство нечег одмах разумљивог, па зато и 'природног' - посезањем за новим концептима и новим угловима разматрања, то наводно природно значење може довести у питање.

Тако, на пример, када је књижевни теоретичар, Едвард Саид (Edward Said), изразио запрепашћење када је открио чињеницу да је већина британских или француских писаца XIX и XX века, којима се одувек дивио, заправо подржавала у својим прозним делима - можда само поштујући тада уобичајене конвенције настајања књижевног дела, уместо са свесном намером - политичку идеологију расизма, тиме је заправо изразио запрепашћење чињеницом да су нека значења једне референцијалне уметности, књижевности, прихватана као 'знање', јер су временом постала толико уобичајена, конвенционална, да су почела да делују као 'природна' или су постајала „невидљива“ колико су била подразумевајућа. ${ }^{26}$ Многа од тих 'природних' значења у књижевности, крила су ужасна наличја - попут поменуте расистичке идеологије - која су откривена када су та значења подвргнута другачијим, новим аналитичким методологијама и концептуалним средствима истраживања.

То се у поменутом случају десило када је концепт Другог који је, према појединим тумачењима настао у црквеном дискурсу, у говорима папе Пије II (Pius PP. II), током XV века, ${ }^{27}$ прихваћен у научном дискурсу. Папа је у својим званичним црквеним говорима, специфичним наративним поступком направио јасну границу између „Ми“, мислећи тада на хришћане и Европљане и „Они“, „Други“ - мислећи тада на муслимане, отоманске Турке, као на апсолутне непријатеље који су након освајања Константинопоља могли да освоје и Рим. ${ }^{28}$ У научном дискурсу је ова подела „Ми Други“, која је могла да укључује разне представнике „Нас“ и „Других“, нарочито постала актуелна током XIX века, у грани психологије која је под називом Völkerpsychologie примењивана у радовима немачких аутора. Током XX века, међутим, ова подела је добила значај и у другим научним дисциплинама попут, на пример,

\footnotetext{
${ }^{26}$ Edward Said, Culture and Imperialism, нав. дело. (Edvard Said, Kultura i imperijalizam, нав. дело)

${ }^{27}$ Више о томе: Tomaž Mastnak, Evropa: med evolucijo in evtanazijo, Ljubljana, Studia humanitatis, Apes 8, 1998. (Tomaž Mastnak, Evropa; Istorija političkog pojma, prev. Milan Đorđević i Dušan Đorđević Mileusnić, Beograd, Beogradski krug, 2007)

${ }^{28}$ Исто, 55-69.
} 
компаративне књижевности. Тада је употребљена у компаративној супдисциплини, тзв. имагологији, у сврху истраживања начина на који једни народи „виде“, доживљавају, у књижевности описују, друге народе. Тако је 1978. године Едвард Саид, написао сада глобално и чувену и оспоравану књигу Оријентализам, у којој је изложио новом углу посматрања и критици - оријенталистички дискурс, тај начин на који западни народи виде, описују, не само у књижевној прози, већ у свим текстовима (медијским, уметничким или научним), разматрају у политичким извештајима, сликају, опевају у канонској поезији, и тако даље, народе на истоку, на тзв. Оријенту. Музикологија је само једна од бројних научних дисциплина која је препознала значај Саидовог открића, које је било дубоко политичко.

Ако се пажња сада врати на узвик XМ, може се приметити да имагологија у овом случају отвара могућност свим слушаоцима који знају концепте и методе имагологије, да рационално изађу из оквира/искуства само чулне перцепције музике. Исто тако, имагологија у овом случају пружа прилику и музикологији да изађе из своје аутономне позиције, из оне врсте анализе нотног записа или звука којом би се утврдило да је у првој великој реченици гудачког квартета ...hold me, neighbor, in this storm... изложена мелодијска линија у деоници гусала, којој се у другој великој реченици придружује мелодијско-ритмички мотив тапана, да би заједно те реченице сачиниле музички период. Имагологија у овом случају пружа музикологији могућност да, уместо псеудотаутолошког понављања и вербализовања онога што је записано нотама, ${ }^{29}$ проговори о питањима која су политичка, која се, на пример, тичу односа између оних индивидуа-репрезената заједница које свирају гусле, оних које свирају тапан и оних које свирају класичне гудачке инструменте.

Али, зашто би се музикологија и за кога, осим за своје потребе, за самопреиспитивање својих метода, тиме уопште бавила, када су политичка питања домен политичког активизма, државне политике или политичке филозофије? Један од познатих одговора је зато што је то иманентно својство саме музичке уметности. Зато што је то одувек било својство уметности, вештине стварања, и свих других људских пракси. Или, на пример, зато што, према речима француског филозофа Жака Рансијера (Jacques Rancière), „политичко“ и музика (и друге уметности) деле једно заједничко својство - моћ прерасподеле чулног у јавном животу, прерасподеле онога што се и ко се у јавности сме чути, видети, осетити. ${ }^{30}$ Али, према речима Мирјане ВеселиновићХофман, нека сагледавања уметничких дела не морају у сваком тренутку историје бити друштвено, идеолошки или научно прихватљива. ${ }^{31}$ Сузан Меклери (Susan McClary) разматрала је питање: због чега је сматрано бласфемијом говорити о Баховој музици у

\footnotetext{
${ }^{29}$ О томе да се оно што је записано у нотама, а потом анализирано и преведено у наратив историје музике не подудара, иако је научни циљ да се остави такав утисак, писано је већ у фусноти бр. 11.

${ }^{30}$ Jacques Rancière, Le Partage du sensible: Esthétique et politique, Paris, La fabrique, 2000. (Žak Ransijer, Sudbina slika; Podela čulnog: estetika i politika, prev. Olja Petronić, Beograd, Centar za medije i komunikacije, Fakultet za medije i komunikacije, Univerzitet Singidunum, 2013; Jacques Rancière, „Raspodjela osjetilnog estetika i politika", prev. Leonardo Kovačević, Up\&Underground br. 09/10, 2006)

31 Мирјана Веселиновић-Хофман, „Позиција уметничког објекта у интердисциплинарном научном окружењу: питања интерпретације“, Зборник Матище српске за сиенску уметност и музику, бр. 41, 2009, 76.
} 
контексту политике његовог времена, некада, исто као и 1950. и 1985. године $^{32}$ Одговор је на први поглед једноставан. У једном тренутку историје, у XVIII веку, или још од времена античке Грчке, како тврди Меклери, идеологија аутономије уметности искључила је не само Бахову, него целокупну уметност из поља јавног говора о друштву. ${ }^{33}$ Тако је музикологија остала затворена у 8 . такту помињане композиције или било којем такту било којег другог музичког дела.

Али, 'идеологија' или 'виђење' музикологије - што су још два битна концепта критичких теорија - као научне дисциплине која у одређеним периодима историје својим резултатима мора да остаје у аутономном свету уметности одвојеном од других сфера друштва (на пример, од политичке сфере) данас је, ако се имају на уму поменута тврдња Мирјане Веселиновић-Хофман и поменуто питање (и одговор) Сузан Меклери, само једна од могућих, допуштених, прихватљивих идеологија, једно од могућих виђења музикологије. Другачија је идеологија она која и уметност и говор о уметности извлачи из оквира ьихове (заједничке) аутономије и смешта, на пример, у свет превирућих, контрадикторних идеја, предлога, захтева, из најразличитијих сфера живота, да се друштва трансформишу у складу са потребама и правима људи, животиња, целокупне природе, уместо по, на пример, данашњем диктату капитала и логике потрошачког друштва и друштва експлоатације. Можда се може тврдити да је данас могућно, прихватљиво да се сваки музиколог (као сваки слушалац или као читалац партитуре) одазове, у складу са својим знањем, врстом и квалитетом образовања које има, друштвеном класом којој припада, друштвеном групацијом којој припада, стилом живота који води, политичким и етичким вредностима које заступа, итд., на ону идеологију која одговара корпусу његових интелектуалних и чулних домета, на ону идеологију која га интерпелира, позива његов ум, како је тврдио Алтисер (Louis Althusser) или његово тело, како је тврдио Фуко (Michel Foucault). ${ }^{34}$

У том случају, поједини музиколози ће бити прозвани идеологијама аутономије уметности и 'уметност ради уметности' и имаће потребу, а подједнако и право, да помињани узвик ХМ, као и звуке гусала, тапана, црквених звона, гласа мујезина, ударања ногама у под и слично, протумаче у својим радовима као обогаћивање звучних боја традиционалног, уметничког гудачког ансамбла. У таквом говору би били у обавези да уоче новине и у третману традиционалне форме гудачког квартета које би уобичајено приписали креативности уметника и музичкој уметности иманентним изменама музичких форми током њене историје. Наслов композиције би могли да протумаче у универзалном контексту, као типично уметнички, хумани позив да се Ми и Други и музичке разноликости које су симболи тог Ми и тог Други - звуци архаичних и модерних инструмената, као и звуци-симболи различитих религија, споје у једну утопијску целину, типично уметничку, трансцендентну.

\footnotetext{
32 Susan McClary, „The blasphemy of talking politics during Bach Year“, in: Richard Leppert and Susan McClary (Eds.) Music and Society: The Politics of Composition, Performance and Reception, Cambridge-New York-Melbourne, Cambridge University Press, 1996 [1987], 13-62.

${ }^{33}$ Сузан Меклери тврди да аутономија датира још од Питагориног времена. Исто, 15.

${ }^{34}$ Louis Althusser, «Ideologie et appareils idéologiques d'État (notes pour une recherche)», La Pensée, no 151, 1970. (Luj Altiser, Ideologija i državni ideološki aparati /beleške za istraživanje/, prev. Andrija Filipović, Loznica, Karpos, 2009, 64)
} 
Други музиколози би, интерпелирани, на пример, идеологијом феминизма након примењене потпуно исте традиционалне формалне анализе или неке друге врсте анализе - уочили да се гудачком квартету који је изворно мушки ансамбл, јер је чак и у XIX веку, још увек било непримерено да жене свирају гудачке инструменте и тиме нарушавају своје држање, добијају модрице на телу од прислањања виолине на врат и слично, додају архаични инструменти. Те одабране архаичне инструменте, приметили би, такође су увек традиционално изводили мушкарци, најмање да би на њима свирали, колико да би уз њих певали о ратовима које су водили они или њихови преци, или да би снагом и врстом звука тих инструмената производили буку и сигнале, најчешће ратничке. Феминистички музиколози би уочили патријархални звук композиције ...hold me, neighbor, in this storm... и разматрали питање да ли се тај патријархални звук занимљиво дестабилизује, доводи у питање када композицију изводе жене или се, напротив, тиме још лакше уочава. У овом другом случају, постављали би питање због чега једна композиторка инсистира на звуку који је симбол патријархата.

Трећа група музиколога би, вођена на пример истраживањима постколонијалних научника и терминологијом којом се они користе, могла да уочи у гудачком квартету ...hold me, neighbor, in this storm... инсистирање на „егзотици“, „нецивилизованом“, „примитивном“ звуку архаичних, ратничких инструмената одређеног поднебља (препознатог или не), суочавањем са звуком инструмената на којима се изводи уметничка музика и смештањем тог архаичног звука инструмената, као и звука узвика ХМ и А, и ударања ногом у под, уз додељене ознаке за извођење: groan, like barking, very dramatic, fierce, у институције изворно буржоаских концертних сала. Ту „егзотичност“ би онда, након исте формалне анализе које би спровели и музиколози 'прозвани' другим идеологијама, могли да тумаче као уметничку субверзију света уметности или као искоришћавање тзв. егзотике на глобалном тржишту које егзотику пласира као производ који се данас најлакше продаје.

Чини се да је данас музиколозима, конституцијом света у којем живимо, омогућено да буду свеснији разноликости идеолошких позиција које могу да заузимају приликом тумачења музичке уметности. Ту могућност, међутим, не користе сви музиколози. Поједини музиколози се свесно праве да не разумеју прилику која им се већ деценијама пружа. У том смислу је занимљиво својевремено 'затварање очију' истакнутог музиколога и пијанисте, Чарлса Розена. Када је 1994. године између Розена и Лоренса Крејмера вођена кратка, али оштра преписка у вези са критиком коју је Розен упутио Крејмеру и другим представницима Нове музикологије, Розен је пре свега указивао на наводне грешке у формалној анализи које је проналазио у радовима представника Нове музикологије, као да такве грешке нису постојале у радовима чији су аутори заступали исту идеологију аутономије музике као и Чарлс Розен. Розен је, интелектуалне љубазности ради, похвалио трагања за тада новим, контекстуалним тумачењима музике којима су се посветили представници Нове музикологије, али је тврдио да, према његовом мишљењу, један од најзначајнијих представника међу њима, композитор Лоренс Крејмер, нема искуство свирања клавира и да зато није довољно 'слушно осетљив' на поједине нарочито битне детаље у Бетовеновој (Ludwig van Beethoven) музици о којој је писао. Крејмер је Розену скренуо пажњу на то да је Розену 
то 'пијанистичко искуство' последње уточиште из којег он може да брани једну идеологију коју су развој друштва и време демантовали. Замерио му је што тврди да је искуство слушања фиксно, непроменљиво, да се заснива на бинарној опозицији: Тачно као Истинито vs. Погрешно, уместо да прихвати чињеницу да музика заправо захтева мноштво „дисконтинуираних, фрагментарних искустава“ која укључују мишљење, меморију, жељу, променљивих интензитета. А све то се подједнако односи на слушање, извођење или мишљење о музици. С једне стране, у преписци између Розена и Крејмера вођена је полемика око тога из које идеологије (у савременом сложеном значењу тог концепта) сме да говори савремени музиколог и за кога. Розен је свој текст започео необичном тврдњом да се „скоро сви слажу у томе да су извођење и слушање музике примарне активности, док је писање о музици секундарно и паразитско“, те да „у идеалном случају музиколози пишу за слушаоце и извођаче, а реално, за друге музикологе. Зато што то морају“. Као изврстан музиколог, и не толико цењен пијаниста, Розен је на сопственом примеру показао како се „пуца себи у ногу“ када се заступа одређена идеологија без познавања њене сложености. При том, свој текст је насловио Music à la Mode. Данас, скоро двадесет пет година касније, испоставља се да је свет од симболичне 1989. године, или те године кратке музиколошке расправе, 1994. остао у основи исти, са многим условима живота који су драстично погоршани, док су тек у неким детаљима побољшани. У том смислу, показало се да је Розен погрешио када је, из своје носталгије за светом који је одавно нестао, проценио да промене које су крајем XX века захватиле музикологију неће трајати дуже од пролазне моде. Крејмер је можда погрешио онолико колико су погрешили сви они који су се надали да ће откривање наличја многих 'знања' које је наметнула идеологија аутономије уметности, допринети подизању свести о томе да ни уметност није увек чаролија, и тиме колико је то могућно допринети промени набоље света у којем живимо. Без обзира на то у којој мери су те наде до данас изневерене или испуњене, наличја уметности данас морају да познају сви: и финансијери уметности (мецене или порески обвезници) и композитори који више не могу себи да приуште скривање иза интуиције и апстракције, нарочито не онда када сарађују са, на пример, олигархијом која уметност користи да би прикрила своје злочесте акције, ${ }^{35}$ и извођачи који бирају чија дела ће да свирају, и музиколози и

\footnotetext{
${ }^{35}$ Овде ће бити наведен само један од примера олигархијске инструментализације идеологије „чаролије“ уметности и прикривања, помоћу уметности, олигархијских послова штетних за многе друштвене групације. Реч је о примеру из Велике Британије о којем говори Енди Хјуит (Andy Hewitt), а разматра Борис Чучковић (Boris Čučković, „Autonomija danas”, Teorija koja Hoda, časopis za teoriju izvođačkih umetnosti, 2012, br. 20, 16-21). Одабрани пример из Велике Британије, данас је готово правило у многим државама. Овај део текста у фусноти преузет је из књиге: Valentina Radoman, Muzika, Politika, Užitak: Funkcije politike i ideologije u muzičkom modernizmu, Beograd, Orion Art, 2018, 19-20.
}

Тако, на пример, Енди Хјуит идентификује три начина на који је у Великој Британији инструментализована (аутономна) уметност данас, односно у време владавине лабуриста, од 1997. до 2010. године. Иста врста инструментализације уметности, међутим, може се уочити и у другим државама. Први начин инструментализације подразумева увођење уметности у јавни простор у виду подстицања уметничке проблематизације свих питања која би допринела подржавању развоја цивилног друштва као демократског друштва јавне расправе и преговора између друштвених група. Други вид коришћења уметности у државне сврхе односи се на третман уметности као помоћног средства у „урбаној регенерацији” и „ребрендирању” постиндустријских градова, док трећи облик инструментализације тзв. аутономне уметности подразумева партиципирање „економски маргинализованих” грађана у свету уметности, како би тиме био подстакнут њихов успон на друштвеној лествици. Међутим, напомиње Хјуит, у исто 
сви слушаоци. Они који желе да путем музичке чаролије побегну од 'приземне свакодневице' могу то да учине, на рачун оних који ће о различитим фасетама уметности мислити, уз помоћ свих могућих концепата који су данас теорији уметности на располагању. Понекад ће они који беже и они који мисле, радо мењати места. Али, то неће променити чињеницу да су данас, насупрот ономе што је тврдио Розен, примарне активности: и извођење и слушање музике и размишљање о музици самој, и размишљање о музичком контексту. И чињеницу да је због тога пожељно да добре музиколошке радове читају и финансијери и композитори и извођачи и слушаоци, од којих су сви припадници различитих идеолошких, класних, друштвених групација. Помало циничан одговор на Розенову тврдњу да „у идеалном случају музиколози пишу за слушаоце и извођаче, а реално, за друге музикологе. Зато што то морају“ сада би гласио да данас музиколози најмање морају да пишу за друге музикологе. Музиколози данас морају да, због развоја својих музиколошких компетенција, добро пазећи да се притом не претворе у „трговце Смислом-свега у свемиру“, како у другом контексту каже Тери Иглтон, ${ }^{36}$ читају књиге из области филозофије, политичке филозофије, политичке географије, социологије, антропологије, теорије књижевности, теорије уметности, психоаналитичке теорије, а време које им од тога преостане свакако ће посветити читању музиколошких књига. Али, само оних најбољих, чији аутори подједнако добро могу да опишу начин стварања музичког дела, одлично се користећи формалном или неком бољом музичком анализом, као и да значење и смисао тих музичких дела протумаче, из идеологије којом су прозвани, у контексту света у којем живе.

Чини се као да је дошло неко време у којем надахнути, критичкој интердисциплинарности наклоњени музиколози више желе/чине добро свету, него многи уметници, наводни творци чаролија, а заправо, врло често жртве потрошачког друштва и друштва експлоатације.

време док је аутономна уметност у Великој Британији поменутог периода била у функцији производње утиска позитивне друштвене промене, државна политика је заправо спроводила приватизацију јавног сектора, смањивала транспарентност владања и продубљивала друштвене поделе (Andy Hewitt, 2012. Art and counter-publics in Third Way cultural policy. PhD dissertation, University of the Arts London. http://ualresearchonline.arts.ac.uk/5679/ ).

Дакле, уметност је тиме имала, заправо, супротну улогу у друштву од оне која се на површини показивала, тако да је својим наводним аутономним статусом и новопреузетом улогом посредника у друштву - која је аутономни статус на сложен начин поништила - доприносила управо правом разарању јавне сфере као места комуникације грађана и државе.

${ }^{36}$ Terry Eagleton, After Theory, London, Penguin Books, 2003. (Terry Eagleton, Śto nakon teorije?, prev. Darko Polšek, Zagreb, Algoritam, 2005, 75.) 
Табела бр. 1: Избор концепата из музикологије које је могућно редефинисати, и концепата из различитих научних дисциплина или области, који се могу користити у музикологији.

\begin{tabular}{|c|c|c|c|c|}
\hline Музикологија & Књижевна теорија & $\begin{array}{l}\text { Историја и } \\
\text { теорија } \\
\text { визуелних } \\
\text { уметности }\end{array}$ & $\begin{array}{l}\text { Пост- } \\
\text { колонијалне } \\
\text { студије }\end{array}$ & $\begin{array}{l}\text { Друштвена } \\
\text { критичка теорија }\end{array}$ \\
\hline $\begin{array}{l}\text { Апсолутна } \\
\text { музика }\end{array}$ & Аутор & $\begin{array}{l}\text { Агонија } \\
\text { модернизма }\end{array}$ & Амбиваленција & $\begin{array}{l}\text { Анти- } \\
\text { Глобализација }\end{array}$ \\
\hline $\begin{array}{l}\text { Аутентично } \\
\text { извођење } \\
\text { музичких дела }\end{array}$ & $\begin{array}{l}\text { Аутореференци- } \\
\text { јалност (језика) }\end{array}$ & $\begin{array}{l}\text { Акритичка } \\
\text { критика }\end{array}$ & Афект & $\begin{array}{l}\text { Ауто- } \\
\text { стереотипизација }\end{array}$ \\
\hline $\begin{array}{l}\text { Аутономија } \\
\text { музичке } \\
\text { уметности } \\
\end{array}$ & Границе тумачења & Апропријација & $\begin{array}{l}\text { Балкан као } \\
\text { метафора }\end{array}$ & Буржоазија \\
\hline Виртуозитет & $\begin{array}{l}\text { Други као } \\
\text { Непријатељ }\end{array}$ & $\begin{array}{l}\text { Дискурзивна } \\
\text { анализа }\end{array}$ & Деколонизација & Глобализација \\
\hline $\begin{array}{l}\text { Емоције (у } \\
\text { музици) }\end{array}$ & $\begin{array}{l}\text { Задовољство у } \\
\text { тексту }\end{array}$ & $\begin{array}{l}\text { Дискурс } \\
\text { господара }\end{array}$ & Расни Други & Дијаспора \\
\hline $\begin{array}{l}\text { Идеологија гласа } \\
\text { (типологија } \\
\text { оперских гласова) }\end{array}$ & Знак & $\begin{array}{l}\text { Дух времена као } \\
\text { Обрт у историји }\end{array}$ & $\begin{array}{l}\text { Евро- } \\
\text { центричност }\end{array}$ & $\begin{array}{l}\text { Државни идеолошки } \\
\text { апарати }\end{array}$ \\
\hline $\begin{array}{l}\text { Интерпретација } \\
\text { (формалне } \\
\text { анализе) } \\
\end{array}$ & Згуснути опис & $\begin{array}{l}\text { Еколошка } \\
\text { уметност }\end{array}$ & Егзотичност & $\begin{array}{l}\text { Државни репресивни } \\
\text { апарати }\end{array}$ \\
\hline $\begin{array}{l}\text { Историја } \\
\text { (музике) }\end{array}$ & Идиом/институција & Иконологија & $\begin{array}{l}\text { Замишљање као } \\
\text { знање }\end{array}$ & Друштвене групације \\
\hline Историје музике & Интенција аутора & Кич & Идеја Европе & $\begin{array}{l}\text { Друштво } \\
\text { експлоатације }\end{array}$ \\
\hline (Јавни) концерт & Интертекстуалност & Контекст & $\begin{array}{l}\text { Имагинарни } \\
\text { Балкан }\end{array}$ & $\begin{array}{l}\text { Друштвена } \\
\text { мобилност }\end{array}$ \\
\hline Кастрат & Канон & Крај уметности & Империјализам & Елита \\
\hline $\begin{array}{l}\text { Музика као } \\
\text { култура }\end{array}$ & Код & $\begin{array}{l}\text { Критика } \\
\text { хуманизма }\end{array}$ & Канон & Идеологија \\
\hline Музичко дело & Контекст & Манифест & $\begin{array}{l}\text { Колонијална } \\
\text { жеља }\end{array}$ & Интерпелација \\
\hline Музички лепо & Метајезик & Перформанс & Компрадор & Институција \\
\hline Опера & Наратив & Поглед & Контрадискурс & Капитал \\
\hline Оригиналност & Означено & Полижанровско & Лиминалност & Класа \\
\hline $\begin{array}{l}\text { Перформативност } \\
\text { музичког дела }\end{array}$ & Означитељ & $\begin{array}{l}\text { Политичка } \\
\text { уметност }\end{array}$ & Модернизација & Колективно сећање \\
\hline $\begin{array}{l}\text { Перцепција } \\
\text { музичког дела }\end{array}$ & Отворено дело & Постисторијско & Оријентализам & Модернизација \\
\hline $\begin{array}{l}\text { Популарна } \\
\text { музика }\end{array}$ & Перцепција & $\begin{array}{l}\text { Радикални } \\
\text { модернизам }\end{array}$ & $\begin{array}{l}\text { Подређени (eng. } \\
\text { subaltern) }\end{array}$ & Мултикултурализам \\
\hline $\begin{array}{l}\text { Поруџбина } \\
\text { музичког дела }\end{array}$ & Референцијалност & Репрезентација & $\begin{array}{l}\text { Постколо- } \\
\text { нијално тело }\end{array}$ & Национализам \\
\hline Семиотика гласа & Смрт аутора & Свет уметности & Примитивно & Олигархија \\
\hline $\begin{array}{l}\text { Слаби појам } \\
\text { модерног }\end{array}$ & Стил & Сећање & Стигма & $\begin{array}{l}\text { Постиндустријско } \\
\text { друштво }\end{array}$ \\
\hline $\begin{array}{l}\text { Смрт уметничке } \\
\text { музике }\end{array}$ & Страх од утицаја & $\begin{array}{l}\text { Уметност као } \\
\text { роба }\end{array}$ & Траума & Простор \\
\hline $\begin{array}{l}\text { Теорија } \\
\text { композитора }\end{array}$ & $\begin{array}{l}\text { Текст (од дела ка } \\
\text { тексту) }\end{array}$ & $\begin{array}{l}\text { Уметност као } \\
\text { процес истине }\end{array}$ & $\begin{array}{l}\text { Хегемонијска } \\
\text { историографија }\end{array}$ & Стереотип \\
\hline $\begin{array}{l}\text { Тотално } \\
\text { уметничко дело }\end{array}$ & Хетероглосија & $\begin{array}{l}\text { Хибридне } \\
\text { уметности }\end{array}$ & Цивилизовано & Утопија \\
\hline Фестивал & Хоризонт очекивања & Цинизам тактика & Центар/маргина & Хегемонија \\
\hline
\end{tabular}


Табела бр. 2: Избор концепата из различитих научних дисциплина или области, који се могу користити у музикологији.

\begin{tabular}{|c|c|c|c|c|}
\hline Филозофија & $\begin{array}{l}\text { Студије рода - } \\
\text { феминизам }\end{array}$ & $\begin{array}{l}\text { Студије } \\
\text { културе }\end{array}$ & Студије тела & $\begin{array}{l}\text { Психоаналитичка } \\
\text { теорија }\end{array}$ \\
\hline Aypa & Десубјективизација & $\begin{array}{l}\text { Активни } \\
\text { конзумент }\end{array}$ & Бол & Анти-Едип \\
\hline Аутентичност & $\begin{array}{l}\text { Доминантна } \\
\text { фикција }\end{array}$ & $\begin{array}{l}\text { Алтернативне } \\
\text { културе }\end{array}$ & Генерација & Велики Други \\
\hline Деконструкција & $\begin{array}{l}\text { Естетичко је } \\
\text { политичко }\end{array}$ & Антиелитизам & $\begin{array}{l}\text { Дисциплиновано } \\
\text { тело }\end{array}$ & $\begin{array}{l}\text { Дискурс } \\
\text { аналитичара }\end{array}$ \\
\hline Детериторијализација & Жртвовање & Генерација & Детињство & Дискурс господара \\
\hline Дисеминација & Феминитет & $\begin{array}{l}\text { Готске } \\
\text { маштарије }\end{array}$ & Емоција & $\begin{array}{l}\text { Дискурс } \\
\text { универзитета }\end{array}$ \\
\hline Дискурс & Физички Други & Декодирање & Гест & Дискурс хистерика \\
\hline Догађај & Идентитет & $\begin{array}{l}\text { Дискурси } \\
\text { мањина }\end{array}$ & Глас & $\begin{array}{l}\text { Друштвена } \\
\text { продукција Едипа }\end{array}$ \\
\hline Душа & Јавна сфера & Доминација & Говор & Жеља \\
\hline $\begin{array}{l}\text { Екстаза } \\
\text { комуникације }\end{array}$ & $\begin{array}{l}\text { Конструкција } \\
\text { женске хистерије }\end{array}$ & $\begin{array}{l}\text { Доминантне } \\
\text { вредности }\end{array}$ & Звук тела & Идентитет \\
\hline $\begin{array}{l}\text { Капитализам и } \\
\text { шизофренија }\end{array}$ & $\begin{array}{l}\text { Култура као } \\
\text { „мушкарац“ }\end{array}$ & $\begin{array}{l}\text { Друштво } \\
\text { спектакла }\end{array}$ & Киборг & Имагинарно \\
\hline Империја & „Кућна“ уметност & $\begin{array}{l}\text { Друштвена } \\
\text { пракса као } \\
\text { култура }\end{array}$ & Ментална болест & $\mathrm{Ja}$ \\
\hline Метаполитика & $\begin{array}{l}\text { Лично је } \\
\text { политичко }\end{array}$ & $\begin{array}{l}\text { Интелектуално } \\
\text { поље }\end{array}$ & Moh & Jouissance \\
\hline Мимезис & Маскулинитет & Класни укуси & Oceћaj (чуло) & Несвесно \\
\hline Мноштво & $\begin{array}{l}\text { Политика } \\
\text { искључивања }\end{array}$ & $\begin{array}{l}\text { Комерцијална } \\
\text { култура }\end{array}$ & Поглед/виђење & Објект мало $a$ \\
\hline Моћ & $\begin{array}{l}\text { Право жена на } \\
\text { образовање }\end{array}$ & $\begin{array}{l}\text { Контингентност } \\
\text { значења }\end{array}$ & Сексуалност & Поглед \\
\hline Политика & Патријархат & $\begin{array}{l}\text { Култура као } \\
\text { политичка } \\
\text { идеологија }\end{array}$ & Слушање & Реално \\
\hline Политичко & Постхумано & $\begin{array}{l}\text { Култура периода } \\
\text { (или структура } \\
\text { осећања) }\end{array}$ & Сећање & $\begin{array}{l}\text { Симболички } \\
\text { поредак }\end{array}$ \\
\hline Полиција & Приватна сфера & $\begin{array}{l}\text { Културна } \\
\text { политика }\end{array}$ & Смрт & Симптом \\
\hline Поредак дискурса & $\begin{array}{l}\text { Природа као } \\
\text { „жена““ }\end{array}$ & $\begin{array}{l}\text { Културни } \\
\text { популизам }\end{array}$ & Старост & Скопофилија \\
\hline Простор & $\begin{array}{l}\text { Савршена } \\
\text { видљивост жене }\end{array}$ & Неједнакост & Стигма & Субјект \\
\hline Свет уметности & Смрт „жене““ & $\begin{array}{l}\text { Популарна } \\
\text { култура }\end{array}$ & Тело & Сублимација \\
\hline Симулакрум & Субјект & Посткултура & Тело извођача & Фаза огледала \\
\hline Субјект & $\begin{array}{l}\text { Темељно } \\
\text { непрепознавање }\end{array}$ & $\begin{array}{l}\text { Потрошачка } \\
\text { култура }\end{array}$ & $\begin{array}{l}\text { Тело са } \\
\text { инвалидитетом }\end{array}$ & $\begin{array}{l}\text { Фаза звучног } \\
\text { огледала }\end{array}$ \\
\hline
\end{tabular}




\begin{tabular}{|l|l|l|l|l|}
\hline Текст & $\begin{array}{l}\text { Транснационални } \\
\text { феминитет }\end{array}$ & $\begin{array}{l}\text { Процедуре } \\
\text { свакодневне } \\
\text { креативности }\end{array}$ & Тело у култури & Фантазам \\
\hline Тело без органа & $\begin{array}{l}\text { Унутрашњи } \\
\text { патријархат }\end{array}$ & $\begin{array}{l}\text { Робна природа } \\
\text { популарне } \\
\text { културе }\end{array}$ & $\begin{array}{l}\text { Тело у } \\
\text { приватности }\end{array}$ & Фетиш \\
\hline Траг & $\begin{array}{l}\text { Фемин. стратегија } \\
\text { укључивања }\end{array}$ & $\begin{array}{l}\text { Хегемонијски } \\
\text { код }\end{array}$ & Тело уметника & Хистерија \\
\hline
\end{tabular}

\section{Коришћена литература}

Eagleton, Terry: Literary Theory: An Introduction. Oxford: Blackwell, 1983. (Terry Eagleton: Književna teorija. Prev. Mia Pervan-Plavec. Zagreb: Liber, 1987.)

Eagleton, Terry: After Theory. London: Penguin Books, 2003. (Terry Eagleton: Što nakon teorije?. Prev. Darko Polšek, Zagreb: Algoritam, 2005.)

Илић, Ивана: Епистемологија савремене музичке анализе. Докторска дисертација (рукопис), Катедра за музикологију, Београд: Факултет музичке уметности, 2016.

Jankélévitch, Vladimir : La Musique et l'Ineffable. Paris: Armand Colin, 1961. (Vladimir Jankelevič: Muzika i neizrecivo. Prev. Jelena Jelić. Novi Sad: Književna zajednica Novog Sada, 1987.)

Keucheyan, Razmig: Hémisphère gauche: Cartographie des nouvelles pensées critiques. Paris: La Découverte, 2013. (Razmig Kešejan: Leva hemisfera; Kartografija novih kritičkih mišljenja, Beograd: Fakultet za medije i komunikacije, Univerzitet Singidunum, 2016.)

Kramer, Lawrence: In response to "Music à la Mode". The New York Review of Books, june 23, 1994.

Mastnak, Tomaž: Evropa: med evolucijo in evtanazijo. Ljubljana: Studia humanitatis, Apes 8, 1998. (Tomaž Mastnak: Evropa; Istorija političkog pojma. Prev. Milan Đorđević i Dušan Đorđević Mileusnić. Beograd: Beogradski krug, 2007.)

McClary, Susan: „The blasphemy of talking politics during Bach Year“, in: Richard Leppert and Susan McClary (Eds.) Music and Society: The Politics of Composition, Performance and Reception. Cambridge - New York - Melbourne: Cambridge University Press, 1996.

Said, Edward W.: Culture and Imperialism. New York: Vintage Books, 1993. (Edvard Said: Kultura i imperijalizam. Prev. Vesna Bogojević. Beograd: Čigoja štampa/Beogradski krug, 2002.)

Rancière, Jacques: Le Partage du sensible: Esthétique et politique. Paris: La fabrique, 2000. (Žak Ransijer: Sudbina slika; Podela čulnog: estetika i politika. Prev. Olja Petronić. Beograd: Centar za medije i komunikacije, Fakultet za medije i komunikacije, Univerzitet Singidunum, 2013; Jacques Rancière: „Raspodjela osjetilnog - estetika i politika”. Prev. Leonardo Kovačević. Up\&Underground br. 09/10, 2006.) 
Radoman, Valentina: Muzika, Politika, Užitak: Funkcije politike i ideologije u muzičkom modernizmu. Beograd: Orion Art, 2018.

Rosen, Charles: „Music à la Mode”. The New York Review of Books, june 23, 1994.

Шуваковић, Мишко: „Изузетност и сапостојање: Gesamtkunstwerk, интертекстуално и појам разлике“. У: Изузетност и сапостојање. V Међународни симпозијум Фолклор, Музика, Дело. Београд: Факултет музичке уметности, 1997, 30-39.

Šuvaković, Miško: Epistemologija umetnosti ili O tome kako učiti učenje o umetnosti. Beograd: Orion Art, 2008.

Šuvaković, Miško: Pojmovnik teorije umetnosti. Beograd: Orion Art, 2011.

Веселиновић-Хофман, Мирјана: „Контекстуалност музикологије“. Нови Звук, специјално издање Постструктуралистичка наука о музищи. Београд, 1998, 13- 20.

Веселиновић-Хофман, Мирјана: „Позиција уметничког објекта у интердисциплинарном научном окружењу: питања интерпретације“. Зборник Матице српске за сиенску уметност и музику, 41, 2009, 67-77.

\section{Резиме}

Године 1994. вођена је кратка расправа у магазину The New York Review of Books између Чарлса Розена и Лоренса Крејмера о перспективама музикологије. Чарлс Розен је заступао идеју аутономије музике и тврдио да пијаниста може боље да чује музику од оних музиколога који не свирају активно неки инструмент и да потом пијанистамузиколог може своју анализу музичког дела да понуди извођачима и слушаоцима. Изразио је сумњу у „слушну осетљивост“ композитора Лоренса Крејмера, уједно и једног од најзначајнијих представника тада тзв. Нове музикологије, и у Крејмерове музиколошке анализе. Том дискредитацијом Розен је, заправо, упутио критику свим оним музиколозима који су тих година били посегнули за новим тумачењима музике, односно покушајима да превазиђу оквире формалне анализе и формалистичке естетике. Крејмер је у одговору на ту врсту критике приметио да је идеологија аутономије музике из које музику слуша и тумачи Чарлс Розен, идеологија прошлости, примењива на музику XVIII и XIX века, али да је музичко искуство много сложеније од морализаторске бинарне поделе на тачно (Истинито) слушање и погрешно слушање.

У овом раду је изложена теза да је данас могућно користити се различитим идеологијама тумачења музичких дела, у складу са интелектуалним, образовним, чулним, класним, етичким и свим другим потенцијалима којима музиколог располаже. Истакнута је важност критичке способности музикологије да проверава сопствена средства и методе истраживања музике, али је нагласак стављен на истраживање оног критичког потенцијала музикологије који се не односи на музикологију саму, већ прекорачује њене традиционалне оквире. Примена, у савременој музикологији, критичких термина из најразличитијих критичких теорија и научних дисциплина, омогућава данас музиколозима много суптилније анализе и интерпретације музичких 
дела него икада раније. Такве врсте анализе и тумачења музичких дела, када су успешна, могу да буду корисна много већем броју читалаца, него што је то био случај у прошлости. За разлику од традиционалне музикологије која се, према речима Чарлса Розена, углавном обраћала самим музиколозима, а само у идеалним случајевима и извођачима и слушаоцима, данашња интердисциплинарна критичка музикологија, у својим добрим примерцима, неопходна је свима: финансијерима уметности (меценама или пореским обвезницима), композиторима који су данас често жртве тржишта, или маске иза којих се скривају олигарси, извођачима који бирају која музичка дела и како ће да свирају и афирмишу, и свим слушаоцима који нису професионални музичари, али имају потребу да буду обавештени о различитим аспектима музичке уметности. 